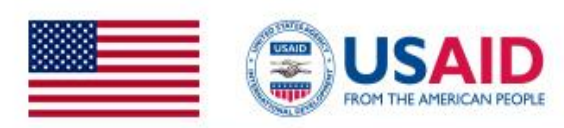

\title{
PAKISTAN
}

Strategy Support Program

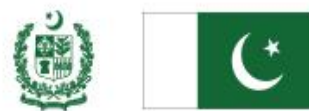

\section{Public Investment Efficiency and Sectoral Economic Growth in Pakistan}

Qazi Masood Ahmed and Syed Ammad Ali 


\section{THE PAKISTAN STRATEGY SUPPORT PROGRAM (PSSP) WOKRING PAPERS}

\section{ABOUT PSSP}

The Pakistan Strategy Support Program (PSSP) is an initiative to strengthen evidence-based policymaking in Pakistan in the areas of rural and agricultural development. Funded by the United States Agency for International Development (USAID) and implemented by the International Food Policy Research Institute (IFPRI), the PSSP provides analysis in four areas: agricultural production and productivity; water management and irrigation; macroeconomics, markets and trade; and poverty reduction and safety nets. The PSSP is undertaken with guidance from the Government of Pakistan through the federal Planning Commission and a National Advisory Committee, and in collaboration with Innovative Development Strategies (Pvt) Ltd. (IDS), Islamabad, and other development partners. For more information, please visit pssp.ifpri.info.

\section{ABOUT the COMPETITIVE GRANTS PROGRAM}

The Competitive Grants Program (CGP) is a component of the PSSP that provides support to Pakistani researchers on topics addressing the PSSP and related objectives. The goals of the CGP are to strengthen social science research within the academic community of Pakistan and to produce quality papers on important development policy issues. While PSSP working papers are not classified as peer-reviewed final publications, the papers developed under the CGP have been presented in program conferences and subject to reviews at the interim and final report stages. The CGP is guided by an academic Research Advisory Committee. For more information on the CGP, please visit pssp.ifpri.info under the tab capacity strengthening/competitive grants program.

This working paper is an output from a CGP grant awarded in June 2012.

\section{ABOUT THE AUTHORS}

Dr. Qazi Masood Ahmed, Director of Research, Institute of Business Administration, Karachi qmasood@iba.edu.pk

Dr. Syed Ammad Ali, Research Fellow, University of Karachi

ammadsyed@yahoo.com 


\section{ACKNOWLEDGMENTS}

We are thankful to David Orden and Andrew Comstock for a series of their very valuable comments on different versions of the paper. This paper is based on the project that was completed with the financial support from an award of the research Competitive Grants Program, Pakistan Strategy Support Program, International Food Policy Research Institute (IFPRI), funded by USAID.

\section{ABSTRACT}

This paper compares the effects of aggregate and sectoral public investments on sectoral private investment, output, and employment. We estimate the elasticities of private investment with respect to aggregate and sectoral public investments to find crowding-out or crowding-in phenomena in Pakistan. The study also reveals the changes in labor absorption or replacement due to additional capital and the effects on output. Our data covers eight sectors of the Pakistan economy and uses annual time series data from 1964 to 2011 . This study uses vector autoregressive (VAR) techniques, as applied by Pereira (2000, 2001), which allows measuring the dynamic feedback effects among the variables. We report forty-eight elasticity coefficients from sectoral and aggregate public investments on the three variables. We conclude that fourteen out of sixteen cases confirm a crowding-in of private investment in the Pakistan economy. This overwhelming majority of cases confirm to us that public investment has a positive effect on private investment. Eleven out of the sixteen elasticity coefficients show public investment has increased labor absorption, and the remaining five show labor is substituted by capital as a result of increased public investment. Similarly, the elasticity coefficients show that in eleven out of sixteen cases, output has increased because of the changes in public investment at the sectoral or aggregate level. These results are consistent with the results of several studies previously conducted on the Pakistani economy but provide more disaggregation and other insights compared to the earlier studies. This analysis suggests that if the government of Pakistan would like to have a significant role from the private sector to increase inclusive growth with more employment in the future, public investment must increase.

We also report a marginal productivity analysis (the effects of per rupee of public investment). Our analysis shows the results obtained from two forms of public investment (sectoral and aggregate) are different, as expected. The comparison for private investment shows that, for six out of eight sectors, the marginal productivity of sectoral investment is more than that of aggregate public investment. It stands to reason that public investment made directly in a sector will have a more profound impact per rupee than aggregate public investment has on the same sector. Overall, sixteen out of twenty-four cases show marginal productivities of sectoral public investments are higher than those for aggregate public investment when we consider private investment, output, and employment variables in our analysis. 


\section{TABLE OF CONTENTS}

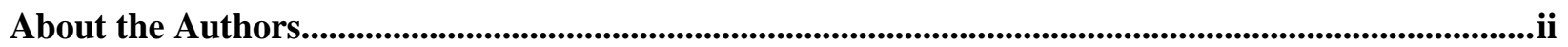

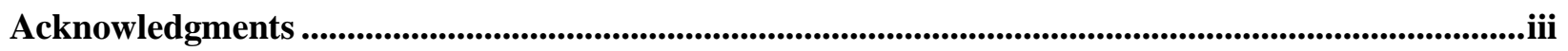

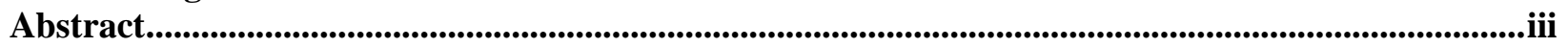

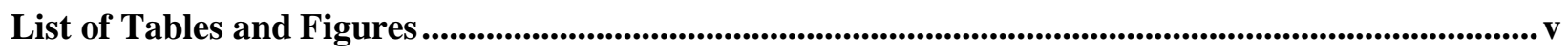

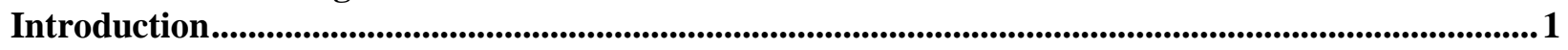

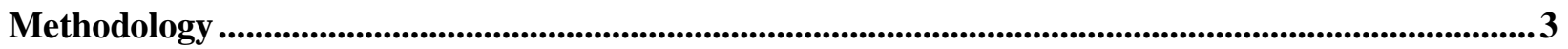

Data Sources and Description ........................................................................................................................................ 4

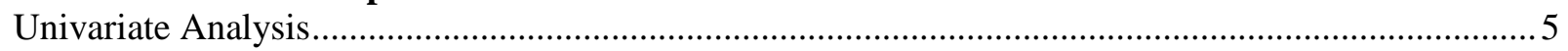

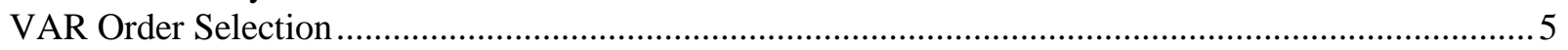

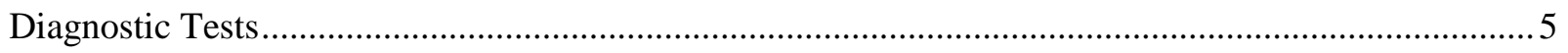

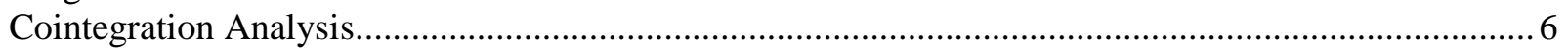

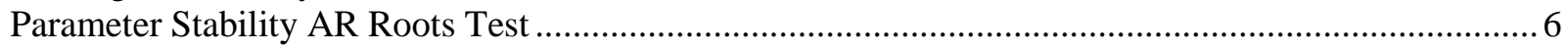

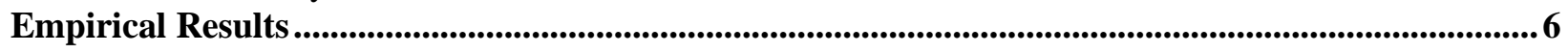

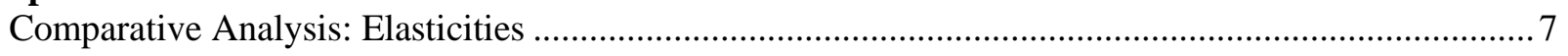

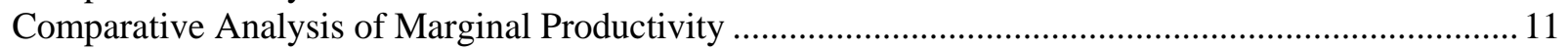

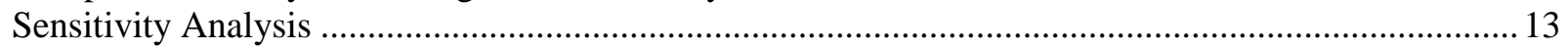

Conclusions and Policy Implications............................................................................................................. 15

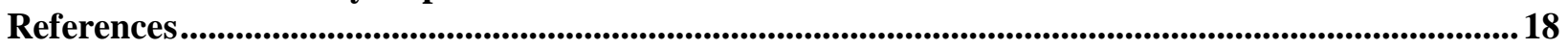

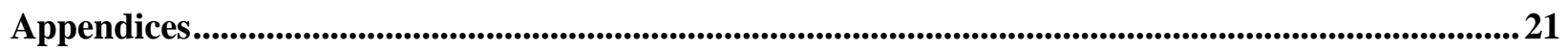

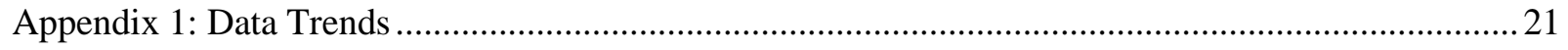

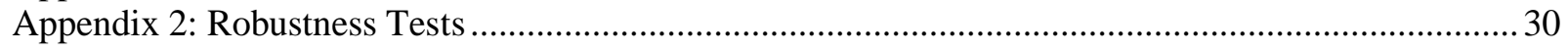

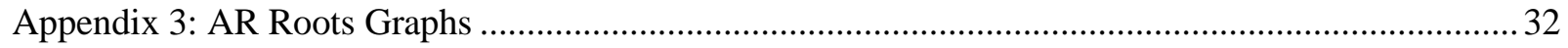

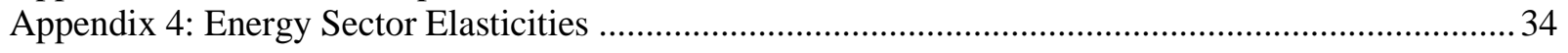




\section{LIST OF TABLES AND FIGURES}

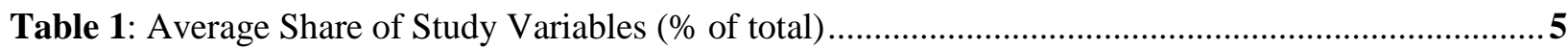

Table 2: Long Term Accumulated Impulse Response Effects of Aggregate and Sectoral Public

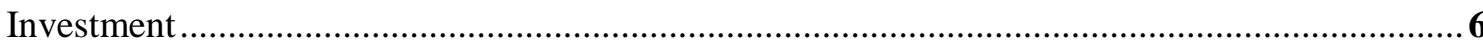

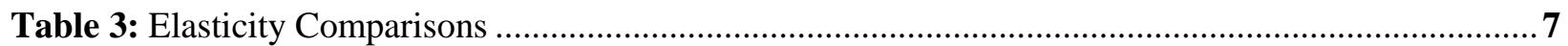

Table 4: Situation 1 - All Private Sector Variables are Positively Affected by Public Investment............8

Table 5: Situation 2 - Crowding-in of Private Investment and Labour Substitution Effects of Public Investment

Table 6: Situation 3 - Crowding-in of Public Investment and Labor Absorption but Unanticipated

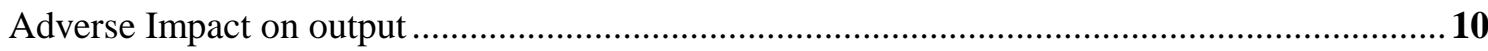

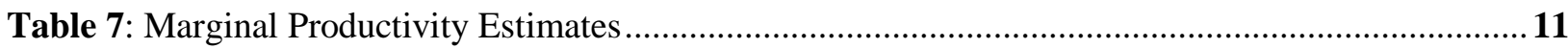

Table 8: Sensitivity Analysis Case 1: Impact of Aggregate public Investment on Agriculture Sector......14

Table 9: Sensitivity Analysis Case 2: Impact of Sectoral Public Investment on Agriculture Sector......... 14

Table 10: Long Term Accumulated Marginal Productivity Variations of Aggregate Public Investment .15

Table 11: Long Term Accumulated Marginal Productivity Variations of Sectoral Public Investment ..... 15

Table A1: Phillips-Perron Unit Root Test StatisticTable 12Phillips-Perron Unit Root Test Statistic ........30

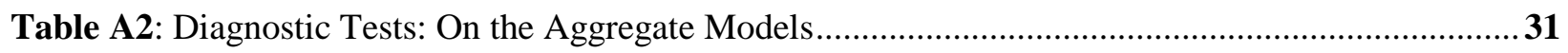

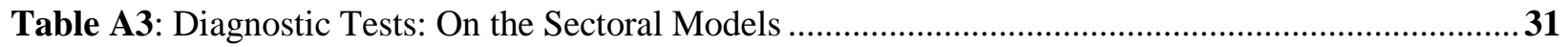

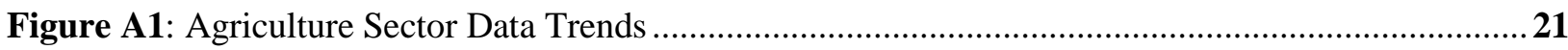

Figure A2: Mining \& Quarrying Sector Data Trends ..................................................................22

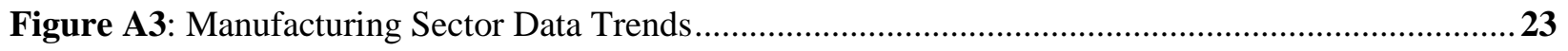

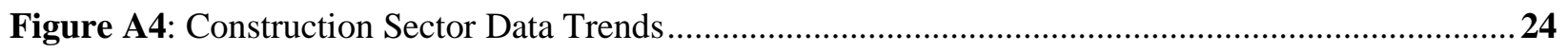

Figure A5: Electricity and Gas Distribution Sector Data Trends.....................................................25

Figure A6: Transport, Storage and Communication Sector Data Trends ...........................................26

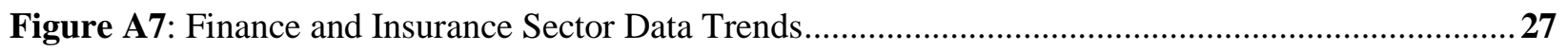

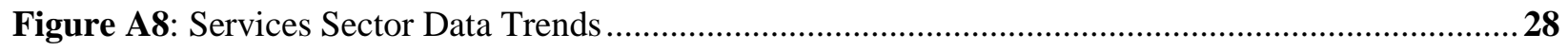

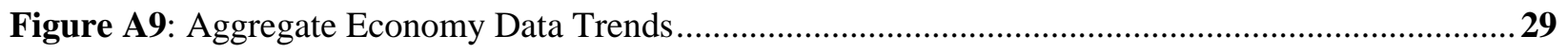

Figure A10: AR Results of Aggregate Public Investment Models ....................................................... 32

Figure A11: AR Results of Sectoral Public Investment Models ...........................................................33 


\section{INTRODUCTION}

The recent successive economic and financial crises have reemphasized the importance of fiscal policy. Modern literature has also revisited the debate regarding the effectiveness of fiscal policy on growth. The issue of the effectiveness of public investment on growth has been debated since the seminal work of Solow (1956). This issue is tackled from many different angles. Some have used a production function approach (Ligthart, 2002; Otto and Voss, 1994, 1996; Sturm and de Haan, 1995, and Wang, 2004). Another seminal work by Aschauer (1989a) led to a series of empirical studies (Aschauer, 1989b, 1989c). These approaches used the single equation method for estimation and captured only the direct effects of public investment on growth. Periera (2000) gave another twist to this literature by highlighting the indirect effects of public investment on output through its effects on other inputs like private investment and employment. Periera's work (1999, 2000, 2001, 2003, 2005, 2007 and 2011) also contributed empirically in this literature by using a vector autoregressive (VAR) technique. This work accounts for both the direct and indirect effects of public investment on growth and also considers the feedback effects of each input into the others in assessing their final effects on output.

The classical school believes that an increment in public spending slows down growth and crowds out the private investment. Since higher spending requires higher taxes at individual or corporate level, it distorts the choices of economic agents and increases the interest rate. Barro (1991), in his most famous work associated with government size, found a negative relationship between growth and government size. Razzolini and Shughart (1997), in the case of the United States, found a negative relationship between growth rate and relative size of government. Parker (1995) found in India a crowding-out effect of overall public investment, while infrastructure investment crowded-in private investment. Alesina et al. (2002) measured the effect of fiscal spending in the case of OECD countries in a Tobin's Q model and confirmed a crowding-out phenomenon. Voss (2002) investigated the crowding-in or out effect in Canada and the US using quarterly data through a VAR model using the variables real GDP, real interest rate, and share of public and private investment to GDP. In both countries he found a negative effect of public investment on private investment. Many other empirical studies found evidence of government expenditures crowding-out, including Ganeli (2003), Engen and Skinner (1992), Folster and Henrekson (2001), Devarajan et al. (1996), Milesi and Roubini, (1998), and Majumdar (2007).

The Keynesians on the other hand, consider government spending as a key variable for economic growth. They argue that development expenditures on health, education, and infrastructure increase labor productivity and reduce costs of doing business which motivates private investment. Many empirical studies support this view. For instance, Chakraborty (2006) examined the real and financial crowding-out or crowding-in effects in India using data from 1971 to 2003 through a VAR model and found that public and private investment are complementary. Easterly and Rebelo (1993) found a positive growth effect of public investment, especially transport and communication. Bose et al. (2007), using data for 30 developing countries, found that government capital expenditures have a positive effect on growth, while at the disaggregate level only education expenditures are positively correlated with growth.

In Pakistan the issue of crowding-in or crowding-out private investment is also hotly debated. One group of policy makers and academics believe that public investment in Pakistan enhances capacity in all sectors and, therefore, output increases because of the crowding-in of public investment. Whereas the opposing group believes public investment in Pakistan is financed by borrowing from money markets and external resources which reduces fiscal space and increases the interest rate, crowding-out private investment.

Recent literature on public spending, and its effects on private investment and output, provides insight for the policy makers in developing countries by using single country data and pooled data of several countries. The literature also covers the impact of aggregate public investment on aggregate and sectoral outputs and components of public investment (i.e. education, infrastructure, and health) on aggregate and sectoral output. In the following paragraphs we tried to cover all of these angles. First, we discuss a few papers which are based on the data of a single country.

Pereira and Oriol (2001) analyzed the marginal productivity (effect per unit of public investment) with respect to public infrastructure investment on private investment, output, and employment in Spain using the VAR methodology. The study was based on five VAR models: one for the aggregate level and the remaining four were for agriculture, services, manufacturing, and construction. The results indicated that, at the aggregate level, public 
infrastructure investment had a positive marginal productivity effect on each variable. At the sectoral level, public investments generally had a positive output; marginal productivity effects for manufacturing, services and construction with respect to private investment and employment were positive. However, in the case of agriculture investments, there were negative marginal product effects on output, private investment, and employment. The highest output marginal productivity effect was found in the case of manufacturing with a marginal effect of 2.43 , indicating one peseta will generate 2.43 pesetas output.

Pereira and Andraz (2005) analyzed the effect of aggregate investment in public transportation, infrastructure, and its components (national roads, municipal roads, highways, ports, airports, and railways) on aggregate private investment, aggregate output, and employment in Portugal by using a VAR approach with annual data from 1976 to 1998. They found that in the long term, an increase of aggregate public infrastructure investment of one euro generated an output increase of 9.5 euros and also had a positive effect on private investment and employment. At a disaggregated level, they found similar trends on output, employment, and revenue. Pereira and Sagales (1999), using a VAR model for Spain, found a crowding-in effect of public capital, leading to increased private output and employment. Baotai (2004) analyzed the effect of public investment through cointegration models during the period of 1961 to 2000 for Canada and found mixed results; some public expenditure, such as health and education, had a positive effect while infrastructure and social security had a negative growth effect.

Pina and Aubyn (2006) examined the rate of return of public investment in the case of the US economy using a VAR model for the period of 1956-2001. The study used four variables; real private investment, real public investment, private employment, and real private GDP. They found a positive partial-cost dynamic feedback rate of return of $7.33 \%$, while the total, or full-cost dynamic feedback, came out to be $3.68 \%$. Pereira (2001) estimated this VAR model with private gross domestic product, private investment, public investment, and private employment for the US economy and both private and public investment were further disaggregated into highways and streets, electric and gas facilities, sewage, water supply, education, hospital building, and development structure. At the aggregate level he found that public investment had a positive effect on private investment, the marginal productivity effect was 4.5 with an annual rate of return of 7.8\%. Pereira and Andraz (2003) examined the effect of aggregate public investment on aggregate private output, employment, and private investment in the US using a VAR impulse response methodology and found, at the aggregate level, public investment had a positive effect on all variables. The study found that an investment of one million dollars will generate twenty-sven new jobs in the long term, and a one dollar investment of public investment will create $\$ 1.11$ of private investment and \$4.99 of output with an annual rate of return of $8.4 \%$. Pereira and Andraz (2003) further analyzed the effect of aggregate public investment at the disaggregate level and found six out of the twelve industries studied had a positive employment effect. In five of these industries crowding-in of private investment prevailed, while in the case of output, 8 out of 12 had a positive effect. Pereira (2000) investigated the effects of aggregate public investment and infrastructure investment at a disaggregate level using a VAR model for the US and found that, at both an aggregate and disaggregate levels, public investment positively affected output and crowded-in private investment. This study estimated a marginal productivity of 4.46 , indicating that a one dollar investment will increase private output by about $\$ 4.46$, and found that the highest rate of returns were in the electric, gas, transit system, and airfield sectors.

The results of the studies using data from several countries also provide useful information. Afonso and Aubyn (2008) utilized an accumulated impulse response function of a VAR model consisting of real interest rate, real output, real taxes, real public investment, and real private investment for 14 European Union countries and some non-European countries, including Japan, Canada, and the United States. The results showed that the output elasticity of private investment was higher than public investment. In most of the countries they found a positive marginal productivity accompanied with a crowding-in effect. Mittnik and Neumann (2001) examined the relationship between public investment, private investment, and output using the VAR model for six industrial countries. Results revealed that public investment crowded-in private investment in three countries only; however, public investment had a positive output effect in all six countries. Kamps (2005) measured the elasticities of private investment, employment, and output with respect to public investment under a VAR estimation technique based on the variables net public capital stock, number of employed persons, real GDP, and private net capital stock. The study was based on twenty-two countries and showed that public capital stock had a positive effect on output in a majority of the countries, excluding Japan and Portugal. Further public investment and private investment were shown to be complementary, and crowding-in exists except in Belgium, Japan, and the US. However, in the case of employment, there was no significant effect of public capital. 
Pereira and Pinho (2011), using the data of twelve euro-zone countries from 1980 to 2003, employed the same methodology and found diverse results. For example, they established that public investment had a positive effect on private investment and employment in all countries except Austria, Belgium, Luxembourg, and the Netherlands. They also concluded that, in the case of Austria, Belgium, Luxembourg, and the Netherlands, public investment had a negative output affect, but in Finland, Portugal, and Spain public investment had a positive growth effect; still, they were unable to generate sufficient tax revenue to finance the public investments. In the case of France, Greece, and Ireland, public investment paid for itself. Finally, in the case of Germany and Italy, public investment not only paid for itself but also generated extra tax revenue.

Such literature is limited in Pakistan. Hyder (2001) examined the effect of real public investment on private investment and growth through a VEC model during 1964 to 2001 and found a complementary relationship between public and private investment and a positive growth effect. Saeed et al. (2006) examined the effect of public investment at the aggregate and disaggregate level in a VAR model using the real variables public investment, employed labor force, GDP, and private investment. The study showed that in agriculture there was crowding-in, while in manufacturing there was crowding-out; at the aggregate level it is inconclusive. Hussain et al. (2009) found that defense and debt servicing crowded-out investment, while development expenditures crowded-in investment. Naveed (2002) showed that public capital formation had a crowding-in effect, however Haque and Montiel (1993) found a crowding-out effect in the case of Pakistan. This study is an addition to the pool of such studies for developing countries including Pakistan. The effectiveness of aggregate public investment on growth is examined in detail in the economic literature, however, the comparative analysis of the impact of aggregate versus sectoral investment is not examined thoroughly but is addressed in the present study. This paper captures both the direct and indirect effects of public investment on sectoral output, highlighting the total size of the impact of public investment on sectoral output and which type and in which sector the public investment is more beneficial in a developing country. This is useful information for policy makers who allocate resources under budgetary constraints.

The remainder of the study is organized as follows: Section 2 illustrates the methodological framework. Section 3 describes the data and presents model diagnostic tests. Section 4 presents the empirical results, and finally the conclusion and policy implications are drawn in Section 5.

\section{METHODOLOGY}

This study is based on the methodology developed by Pereira (2000, 2001) where a vector autoregressive (VAR) technique is used for measuring the effect of public investment on output, private investment, and employment at the sectoral level. This methodology allows us to measure the dynamic feedback effects among the variables. Each VAR model used here consists of public investment, private investment, output, and employment for one sector. The eight sectors are: 1) Agriculture (major crops, minor crops, livestock, and fishing \& forestry); 2) Mining \& Quarrying; 3) Manufacturing; 4) Construction; 5) Electricity and Gas Distribution; 6) Transport, Storage and Communication; 7) Finance and Insurance; and 8) Services (community services, public administration, and defense and ownership of dwellings). Sixteen VAR models are estimated. Each model measures the effect of either sectoral or aggregate public investment on the three sectoral variables. For example, in the agriculture sector model, along with public investment, agricultural private investment, agricultural GDP, and agricultural employment are included in the VAR specification. The VAR models can be defined as:

$$
X_{t}=C+\sum_{i=1}^{p} A_{t} X_{t-i}+\mu_{t}
$$

where $\mathrm{X}$ is the vector of $(4 \mathrm{x} 1), \mathrm{C}$ is the intercept vector also $(4 \mathrm{x} 1), \mathrm{A}$ is the matrix of coefficient $(4 \mathrm{x} 4)$, and $\mu$ is the vector of error terms $(4 \mathrm{x} 1)$. The selection of the variables is proposed in such a way as to cover the policy aspects of public investment as discussed in previous empirical studies. The linear form of the model in natural $\log$ first differences is:

$$
\mathrm{X}_{\mathrm{t}}=\Delta \log \mathrm{IPub}, \Delta \log \text { IPriv, } \Delta \log \mathrm{Y}, \Delta \log \text { Emp }
$$

where IPub, IPriv, Y and Emp are levels of public investment, private investment, employment, and output, respectively.

To measure the effect of public investment on other variables, impulse response functions for each VAR model are generated; measuring the effects of a shock in one endogenous variable on all variables in the model. To 
construct the residual of the VAR that are contemporaneously uncorrelated, the VAR model is modified in such a way that contemporaneous correlation among the residuals are diagonal. To attain these uncorrelated residuals, a Choleski decomposition is used with the variables ordered as in equation (2), (i.e. public investment first and then private investment, output, and employment). The resulting accumulated impulse responses on which we focus measure the cumulative response of all variables due to a change in the policy variable, i.e. public investment. The outcome of the accumulated impulse response function provides the accumulated long term elasticity from the VAR model for a shock to the policy variable. For example:

$$
\varepsilon_{\text {IPUB }}=\frac{\Delta \log Y_{i}}{\Delta \log I P u b_{i}}
$$

The above equation (3) is the long term elasticity of output with respect public investment which is obtained directly through an accumulated impulse response function measuring the accumulated change in the growth rate of different variables. The numerator of this elasticity is the accumulated change in output growth rate of the ith sector. The above elasticity can be transformed into long term marginal productivity by using the following formula multiplying the accumulated long term elasticity by the ratio of the policy variable to the response variable:

$$
M P \equiv \frac{\Delta Y}{\Delta I P u b}=\varepsilon_{I P U B} \frac{Y_{i}}{I P u b_{i}}
$$

The long term accumulated marginal productivity of the policy variable measures the unit change of the VAR model variables due to an unexpected change of one unit in the policy variable. This concept of marginal productivity is different from the conventional concept because it is not based on the assumption on ceteris paribus. Rather, here it refers to the total (dynamic) marginal product as it captures the dynamic feedbacks among the variables. Similarly, equations (3) and (4) can be changed to apply for private investment and employment and can also be modified to replace sectoral investment with aggregate investment for that part of the analysis.

\section{DATA SOURCES AND DESCRIPTION}

This study is based on annual time series data from 1964 to 2011 for all the sectors considered except the finance and insurance sector which starts from 1981 due to non-availability of earlier employment data in this sector. All data series were obtained from the State Bank of Pakistan Annual Report, 50 Years of Pakistan Economy, and various issues of the Economic Survey of Pakistan. All variables are converted into real variables through the GDP deflator for 1999-2000, and their first difference in log form is used in the analysis. There are three GDP deflator series in the Pakistan economic survey: 1959-60, 1980-81, and 1999-2000. The standard splicing technique is used to convert all these deflator series into a common base: 1999-2000. Table 1 shows three sub-period averages for each series, and the graphs of all series are given in Appendix 1. 
Table 1: Average Share of Study Variables (\% of total)

\begin{tabular}{|c|c|c|c|c|c|c|c|c|c|c|c|c|}
\hline \multirow[b]{2}{*}{ Sectors } & \multicolumn{3}{|c|}{ Private Investment } & \multicolumn{3}{|c|}{ Output } & \multicolumn{3}{|c|}{ Employment } & \multicolumn{3}{|c|}{ Public Investment } \\
\hline & $\begin{array}{l}1964- \\
1979 \\
\end{array}$ & $\begin{array}{l}1980- \\
1995 \\
\end{array}$ & $\begin{array}{l}1996- \\
2011 \\
\end{array}$ & $\begin{array}{l}1964- \\
1979 \\
\end{array}$ & $\begin{array}{l}1980- \\
1995 \\
\end{array}$ & $\begin{array}{l}1996- \\
2011 \\
\end{array}$ & $\begin{array}{l}1964- \\
1979 \\
\end{array}$ & $\begin{array}{l}1980- \\
1995 \\
\end{array}$ & $\begin{array}{l}1996- \\
2011 \\
\end{array}$ & $\begin{array}{l}1964- \\
1979 \\
\end{array}$ & $\begin{array}{c}1980- \\
1995 \\
\end{array}$ & $\begin{array}{l}1996- \\
2011\end{array}$ \\
\hline Agriculture & 15.10 & $\overline{17.15}$ & $\overline{12.41}$ & $\overline{34.89}$ & $\overline{27.01}$ & 22.69 & 55.70 & 50.46 & $\overline{44.85}$ & 22.93 & 5.42 & 2.12 \\
\hline Mining \& Quarrying & 0.43 & 0.33 & 4.00 & 0.66 & 0.63 & 2.55 & 0.26 & 0.17 & 0.16 & 0.88 & 4.74 & 12.75 \\
\hline Manufacturing & 33.70 & 35.29 & 27.05 & 15.46 & 16.68 & 17.32 & 14.09 & 12.58 & 12.57 & 20.34 & 12.04 & 6.46 \\
\hline Construction & 1.37 & 2.78 & 2.03 & 4.54 & 4.17 & 2.57 & 3.81 & 5.94 & 6.26 & 2.31 & 7.90 & 4.24 \\
\hline $\begin{array}{l}\text { Electricity and Gas } \\
\text { Distribution }\end{array}$ & 3.09 & 1.27 & 3.92 & 1.33 & 2.72 & 2.80 & 0.42 & 0.79 & 0.73 & 18.03 & 38.58 & 29.42 \\
\hline $\begin{array}{l}\text { Transport, Storage and } \\
\text { Communication }\end{array}$ & 16.25 & 8.31 & 16.32 & 6.92 & 9.18 & 12.19 & 4.53 & 4.95 & 5.48 & 10.76 & 23.42 & 38.63 \\
\hline Finance and Insurance & 0.73 & 0.51 & 4.08 & 2.11 & 2.99 & 4.13 & 0.00 & 0.75 & 0.89 & 0.83 & 1.62 & 1.87 \\
\hline Services & 29.32 & 32.84 & 27.47 & 18.97 & 20.46 & 18.41 & 9.93 & 11.99 & 14.38 & 23.93 & 6.00 & 4.48 \\
\hline Pakistan & 100.00 & 98.49 & 97.29 & 84.87 & 83.84 & 82.66 & 88.75 & 87.62 & 85.32 & 100.00 & 99.73 & 99.98 \\
\hline
\end{tabular}

The data averages in Table 1 show that, among the eight sectors, the highest output share belongs to agriculture throughout the study period followed by services. The third largest output is found in the manufacturing sector, followed by transport, storage and communication, finance and insurance, construction, electricity and gas distribution, and then mining \& quarrying. The private investment trends show that the highest share of private investment goes to manufacturing followed by services, transport, storage and communication, agriculture, electricity and gas distribution, finance and insurance, mining \& quarrying, and then construction. The employment history shows that the highest employment share belongs to agriculture followed by manufacturing, services, construction, transport, storage and communication, electricity and gas distribution, finance and insurance, and then mining \& quarrying. Public investment data shows that the highest share belongs to electricity and gas distribution followed by transport, storage and communication, manufacturing, services, mining \& quarrying, agriculture, construction, and then finance and insurance.

\section{Univariate Analysis}

Univariate Analysis Stationarity of each variable is one of the necessary conditions for estimation and forecasting using the VAR model, and if there is cointegration then the order of integration must be the same. Augmented Dickey-Fuller (1979) and Philips Perron (1988) tests are used to check the order of integration. The final conclusion based on the Philips Perron tests, for which the results are shown in Table A1 of Appendix 2, is that all the variables are non-stationary in levels using a 90\% confidence interval, except three variables which are level stationary.

However, at first difference, all the variables are stationary.

\section{VAR Order Selection}

An appropriate number of lags is a crucial decision for VAR estimation. There are different information criteria available for choosing a more parsimonious model, and we have applied the Schwarz (1978) information criterion (SC) and the Akaike (1974) information criterion (AIC). For each model, lag selection was made on the basis of Schwarz information criterion using different specifications up to four lags. The results reveal ${ }^{1}$ that in most cases one lag is showing a minimum information criterion value; therefore, one lag is used in the VAR models.

\section{Diagnostic Tests}

The results of the diagnostic tests are given in Appendix 2, Tables A2 and A3 for the eight aggregate public investment and eight sectoral public investment models respectively. The results indicate that there is heteroskedasticity in only one case. Results of the LM tests also show serial correlation in only five models. The assumption of normality is also tested in all the cases, and the results do not support the normality assumptions in most of the cases, but we can discount this issue as Lutkepohl (1991) discussed that the VAR parameters estimators do not depend on the normality assumption.

\footnotetext{
${ }^{1}$ Results are not reported for the VAR order selection tests, nor for the cointegration test, but are available on request.
} 


\section{Cointegration Analysis}

Finally, to decide whether to use a vector autoregressive model (VAR) or vector error correction model (VEC), a cointegration test is applied to all the models by using the Engle-Granger (1987) and the Johansen $(1991,1995)$ approaches. The decision of cointegration is based on both tests results. For the majority of the models both tests reject the existence of cointegration. While in few models only the Johansen test shows the existence of cointegration, the joint results of Engle-Granger and Johansen reject the existence of any cointegration. These finding are similar to other related studies e.g. in the case of Portugal (Pereria and Andraz, 2005), and in the case of US (Pereria and Andraz, 2003), where both did not find any cointegration.

\section{Parameter Stability AR Roots Test}

The AR inverse roots are reported in Appendix 3 to measure the stability of the VAR models. The graphs show that all the roots lay inside the unit circle, indicating that the VAR parameters are stable (Lutkepohl 1991).

\section{EMPIRICAL RESULTS}

This section discusses the empirical effects of sectoral and aggregate public investment on sectoral output, private investment, and employment based on the accumulated impulse response functions. The effect of a shock in sectoral public investment on sectoral GDP is traced in terms of output elasticities which show the accumulated response of output to a shock in public investment of each individual sector. The long term accumulated effect of sectoral public investment on private investment is estimated by elasticities of private investment with respect to this public investment. Similarly the effects of sectoral public investment on employment are measured in terms of employment elasticities with respect to the public investment. This section also discusses the comparison of these sectoral results with the results obtained using aggregate public investment.

The study gives forty-eight elasticity coefficients (three for each sector from the sectoral public investment models and three for each sector from aggregate public investment models). A summary of the estimated direction of impact in each case is shown in Table 2 .

Table 2: Long Term Accumulated Impulse Response Effects of Aggregate and Sectoral Public Investment

\begin{tabular}{|c|c|c|c|c|c|c|}
\hline \multirow[b]{2}{*}{ Sectors } & \multicolumn{3}{|c|}{$\begin{array}{c}\text { Impulse Response of Aggregate Public } \\
\text { Investment }\end{array}$} & \multicolumn{3}{|c|}{$\begin{array}{c}\text { Impulse Response of Sectoral Public } \\
\text { Investment }\end{array}$} \\
\hline & $\begin{array}{l}\text { On Private } \\
\text { Investment }\end{array}$ & On Output & $\begin{array}{c}\text { On } \\
\text { Employment }\end{array}$ & $\begin{array}{l}\text { On Private } \\
\text { Investment }\end{array}$ & On Output & $\begin{array}{c}\text { On } \\
\text { Employment }\end{array}$ \\
\hline Agriculture & + & - & + & + & - & - \\
\hline Mining \& Quarrying & + & + & - & + & - & + \\
\hline Manufacturing & + & + & + & + & + & + \\
\hline Construction & + & + & - & + & + & + \\
\hline $\begin{array}{l}\text { Electricity and Gas } \\
\text { Distribution }\end{array}$ & + & - & + & + & - & + \\
\hline $\begin{array}{l}\text { Transport, Storage } \\
\text { and Communication }\end{array}$ & + & + & + & + & + & + \\
\hline $\begin{array}{l}\text { Finance and } \\
\text { Insurance }\end{array}$ & - & + & + & + & + & + \\
\hline Services & + & + & - & - & + & - \\
\hline
\end{tabular}

For private investment, fourteen out of sixteen cases confirm a crowding-in phenomenon in the Pakistani economy. This overwhelming majority confirms to us that public investment has positive effect on private investment. Eleven out of sixteen elasticity coefficients show public investment has increased labor absorptions and the remaining five show labor is substituted by capital as a result of increased public investment. Similarly, the elasticity coefficients shows, that in eleven out of sixteen sectors, output has increased because of the changes in public investment and its subsequent effects on private investment and employment. 


\section{Comparative Analysis: Elasticities}

The aggregate and sectoral public investment effects on the sectoral outcomes are estimated directly without imposing any constraints that tie the estimates together. Theoretically, the elasticity of a sectoral dependent variable (private investment, output and employment) with respect to aggregate public investment is a weighted sum of: 1) the elasticity of that sectoral variable's response with respect to public investment in that sector (this is the sectoral public investment elasticity estimated in our study) plus 2) cross-sector elasticities (e.g. the elasticity of agricultural output with respect to investment in the manufacturing sector and so on; there would be seven such cross-sector terms in an eight sector economy). The weights on each of the eight elasticities (one direct and seven cross-sector) are the elasticity of public investment in that sector with respect to the change in aggregate public sector investment.

The result can work in three directions. The change in a sector's output due to the change in aggregate public investment could be less than, equal to or greater than the change in that sector's output due to a change in sectoral public investment in that sector because the elasticity of investment in that sector with respect to aggregate public investment (the weight on the direct effect) could be less than, equal or greater than one in value and the net cross-sector effects could be positive (for example, if public sector investments in another sector expand demand for the first sector) or negative (for example, if public sector investments in another sector draw resources out of the first sector). In addition to this mathematical relationship embodied in the total derivative, there is the issue that the elasticities for the aggregate public sector investment and sectoral public sector investment models are estimated independently, so there is estimation error affecting a comparison of the two for each sector.

The elasticity results are shown in Table 3. The results show that in fourteen out of twenty-four cases the estimated elasticity with respect to aggregate public sector investment is larger in magnitude than the elasticity with respect to sectoral public investment.

Table 3: Elasticity Comparisons

\begin{tabular}{|c|c|c|}
\hline \multicolumn{3}{|c|}{ Effects on Private Investment } \\
\hline Sector & $\begin{array}{c}\text { Elasticity of Aggregate } \\
\text { Public Investment }\end{array}$ & $\begin{array}{c}\text { Elasticity of Sectoral } \\
\text { Public Investment }\end{array}$ \\
\hline Agriculture & 0.0973 & 0.0174 \\
\hline Mining \& Quarrying & 0.0362 & 0.1177 \\
\hline Manufacturing & 0.1371 & 0.0541 \\
\hline Construction & 0.1485 & 0.1555 \\
\hline $\begin{array}{l}\text { Electricity and Gas } \\
\text { Distribution }\end{array}$ & 0.3733 & 0.0247 \\
\hline $\begin{array}{l}\text { Transport, Storage } \\
\text { and Communication }\end{array}$ & 0.0487 & 0.0502 \\
\hline $\begin{array}{l}\text { Finance and } \\
\text { Insurance }\end{array}$ & -0.038 & 0.0425 \\
\hline Services & 0.0886 & -0.0341 \\
\hline
\end{tabular}




\begin{tabular}{|c|c|c|}
\hline \multicolumn{3}{|c|}{ Effects on Output } \\
\hline Sector & $\begin{array}{l}\text { Elasticity of Aggregate } \\
\text { Public Investment }\end{array}$ & $\begin{array}{l}\text { Elasticity of Sectoral } \\
\text { Public Investment }\end{array}$ \\
\hline Agriculture & -0.0071 & -0.0031 \\
\hline Mining \& Quarrying & 0.1623 & -0.0069 \\
\hline Manufacturing & 0.0065 & 0.0044 \\
\hline Construction & 0.0693 & 0.045 \\
\hline $\begin{array}{l}\text { Electricity and Gas } \\
\text { Distribution }\end{array}$ & -0.0119 & -0.0247 \\
\hline $\begin{array}{l}\text { Transport, Storage } \\
\text { and Communication }\end{array}$ & 0.0131 & 0.0392 \\
\hline $\begin{array}{l}\text { Finance and } \\
\text { Insurance }\end{array}$ & 0.1171 & 0.053 \\
\hline Services & 0.0138 & 0.0009 \\
\hline \multicolumn{3}{|c|}{ Effects on Employment } \\
\hline Sector & $\begin{array}{l}\text { Elasticity of Aggregate } \\
\text { Public Investment }\end{array}$ & $\begin{array}{c}\text { Elasticity of Sectoral } \\
\text { Public Investment }\end{array}$ \\
\hline Agriculture & 0.0002 & -0.0039 \\
\hline Mining \& Quarrying & -0.3584 & 0.0825 \\
\hline Manufacturing & 0.0158 & 0.0083 \\
\hline Construction & -0.0006 & 0.0014 \\
\hline $\begin{array}{l}\text { Electricity and Gas } \\
\text { Distribution }\end{array}$ & 0.0969 & 0.0551 \\
\hline $\begin{array}{l}\text { Transport, Storage } \\
\text { and Communication }\end{array}$ & 0.0014 & 0.0053 \\
\hline $\begin{array}{l}\text { Finance and } \\
\text { Insurance }\end{array}$ & 0.0442 & 0.0072 \\
\hline Services & -0.03 & -0.0087 \\
\hline
\end{tabular}

Using the signs (as shown in Tables 2 and 3) and the magnitudes shown in Table 3, the results can be discussed in three categories, as shown in Tables 4,5 and 6 and discussed below each table.

Table 4: Situation 1 - All Private Sector Variables are Positively Affected by Public Investment

\begin{tabular}{|c|c|c|}
\hline \multicolumn{3}{|c|}{ Effects on Private Investment } \\
\hline Sector & $\begin{array}{c}\text { Elasticity of Aggregate } \\
\text { Public Investment }\end{array}$ & $\begin{array}{c}\text { Elasticity of Sectoral } \\
\text { Public Investment }\end{array}$ \\
\hline Manufacturing & 0.1371 & 0.0541 \\
\hline $\begin{array}{l}\text { Transport, Storage } \\
\text { and Communication }\end{array}$ & 0.0487 & 0.0502 \\
\hline Construction & & 0.1555 \\
\hline $\begin{array}{l}\text { Finance and } \\
\text { Insurance }\end{array}$ & & 0.0425 \\
\hline \multicolumn{3}{|c|}{ Effects on Output } \\
\hline Sector & $\begin{array}{l}\text { Elasticity of Aggregate } \\
\text { Public Investment }\end{array}$ & $\begin{array}{l}\text { Elasticity of Sectoral } \\
\text { Public Investment }\end{array}$ \\
\hline Manufacturing & 0.0065 & 0.0044 \\
\hline $\begin{array}{l}\text { Transport, Storage } \\
\text { and Communication }\end{array}$ & 0.0131 & 0.0392 \\
\hline Construction & & 0.045 \\
\hline $\begin{array}{l}\text { Finance and } \\
\text { Insurance }\end{array}$ & & 0.053 \\
\hline
\end{tabular}




\begin{tabular}{|c|c|c|}
\hline \multicolumn{3}{|c|}{ Effects on Employment } \\
\hline Sector & $\begin{array}{c}\text { Elasticity of Aggregate } \\
\text { Public Investment }\end{array}$ & $\begin{array}{c}\text { Elasticity of Sectoral } \\
\text { Public Investment }\end{array}$ \\
\hline Manufacturing & 0.0158 & 0.0083 \\
\hline $\begin{array}{l}\text { Transport, Storage } \\
\text { and Communication }\end{array}$ & 0.0014 & 0.0053 \\
\hline Construction & & 0.0014 \\
\hline $\begin{array}{l}\text { Finance and } \\
\text { Insurance }\end{array}$ & & 0.0072 \\
\hline
\end{tabular}

Situation 1 (Table 4) shows six cases (two in aggregate and four in sectoral) that fit a positive, Keynesian, economic story of the effects of public investment. All of the coefficients are positive, following the logic that public investment crowds-in private investment, and the new public and private investment increases output and employment, as would be expected from a production function relating output to capital and labor inputs. In general, the estimated effects on employment are, in order of magnitude, smaller than the effects on private investment, and estimated effects on output are smaller than on private investment but larger than the employment effects. This shows the positive effects of public investment are stronger on private investment and also positively affecting the output and employment variable through both direct and indirect effects.

\section{Table 5: Situation 2 - Crowding-in of Private Investment and Labour Substitution Effects of Public} Investment

\begin{tabular}{|c|c|c|}
\hline \multicolumn{3}{|c|}{ Effects on Private Investment } \\
\hline Sector & $\begin{array}{c}\text { Elasticity of Aggregate } \\
\text { Public Investment }\end{array}$ & $\begin{array}{c}\text { Elasticity of Sectoral } \\
\text { Public Investment }\end{array}$ \\
\hline Agriculture & & 0.0174 \\
\hline $\begin{array}{l}\text { Mining \& } \\
\text { Quarrying }\end{array}$ & 0.0362 & \\
\hline Construction & 0.1485 & \\
\hline $\begin{array}{l}\text { Finance and } \\
\text { Insurance }\end{array}$ & -0.038 & \\
\hline Services & 0.0886 & -0.0341 \\
\hline \multicolumn{3}{|c|}{ Effects on Output } \\
\hline Sector & $\begin{array}{c}\text { Elasticity of Aggregate } \\
\text { Public Investment }\end{array}$ & $\begin{array}{c}\text { Elasticity of Sectoral } \\
\text { Public Investment }\end{array}$ \\
\hline Agriculture & & -0.0031 \\
\hline $\begin{array}{l}\text { Mining \& } \\
\text { Quarrying }\end{array}$ & 0.1623 & \\
\hline Construction & 0.0693 & \\
\hline $\begin{array}{l}\text { Finance and } \\
\text { Insurance }\end{array}$ & 0.1171 & \\
\hline Services & 0.0138 & 0.0009 \\
\hline \multicolumn{3}{|c|}{ Effects on Employment } \\
\hline Sector & $\begin{array}{c}\text { Elasticity of Aggregate } \\
\text { Public Investment }\end{array}$ & $\begin{array}{c}\text { Elasticity of Sectoral } \\
\text { Public Investment }\end{array}$ \\
\hline Agriculture & & -0.0039 \\
\hline $\begin{array}{l}\text { Mining \& } \\
\text { Quarrying }\end{array}$ & -0.3584 & \\
\hline Construction & -0.0006 & \\
\hline $\begin{array}{l}\text { Finance and } \\
\text { Insurance }\end{array}$ & 0.0442 & \\
\hline Services & -0.03 & -0.0087 \\
\hline
\end{tabular}

Situation-2 (Table 5) shows six cases (four aggregate and two sectoral) in which public investment shows either crowding-in or crowding-out effects on private capital and there are capital-labor substitution effects. In five out of six cases, output has increased because of these changes. For mining \& quarrying, construction, and services 
(in the aggregate column) we see the situation where public investment crowded-in private investment, but there is a drop in sectoral employment, with a net effect that output went up. This implies, during the production process, these sectors saw crowding-in for private investment along with a substitution of capital for labor. The cumulative effect of an increase in public and private investment and reduction in employment in these three sectors has resulted in a net increase in output.

In finance and insurance (in the aggregate column), public investment crowds out private investment, but there is an increase in employment, i.e. labor has substituted for private capital, along with an increase in output. In services, the sectoral column shows that public investment crowds out private investment; there is a drop in employment bit a slight increase in output. This could present the same story as substituting capital for labor since the elasticity is less than one. There is more public capital coming in than private capital that is leaving on a percentage basis. Finally, in agriculture the sectoral column shows that public investment crowds in private investment, but there is a drop in employment and a drop in output. A plausible reason is that the drop in employment created by the public investment outweighs the increase in public plus private investment leading to a drop in output.

\section{Table 6: Situation 3 - Crowding-in of Public Investment and Labor Absorption but Unanticipated} Adverse Impact on output

\begin{tabular}{|c|c|c|}
\hline \multicolumn{3}{|c|}{ Effects on Private Investment } \\
\hline Sector & $\begin{array}{c}\text { Elasticity of Aggregate } \\
\text { Public Investment }\end{array}$ & $\begin{array}{c}\text { Elasticity of Sectoral } \\
\text { Public Investment }\end{array}$ \\
\hline Agriculture & 0.0973 & \\
\hline $\begin{array}{l}\text { Electricity and } \\
\text { Gas Distribution }\end{array}$ & 0.3733 & 0.0247 \\
\hline $\begin{array}{l}\text { Mining \& } \\
\text { Quarrying }\end{array}$ & & 0.1177 \\
\hline \multicolumn{3}{|c|}{ Effects on Output } \\
\hline Sector & $\begin{array}{c}\text { Elasticity of Aggregate } \\
\text { Public Investment }\end{array}$ & $\begin{array}{c}\text { Elasticity of Sectoral } \\
\text { Public Investment }\end{array}$ \\
\hline Agriculture & -0.0071 & \\
\hline $\begin{array}{l}\text { Electricity and } \\
\text { Gas Distribution }\end{array}$ & -0.0119 & -0.0247 \\
\hline $\begin{array}{l}\text { Mining \& } \\
\text { Quarrying }\end{array}$ & & -0.0069 \\
\hline \multicolumn{3}{|c|}{ Effects on Employment } \\
\hline Sector & $\begin{array}{c}\text { Elasticity of Aggregate } \\
\text { Public Investment }\end{array}$ & $\begin{array}{c}\text { Elasticity of Sectoral } \\
\text { Public Investment }\end{array}$ \\
\hline Agriculture & 0.0002 & \\
\hline $\begin{array}{l}\text { Electricity and } \\
\text { Gas Distribution }\end{array}$ & 0.0969 & 0.0551 \\
\hline $\begin{array}{l}\text { Mining \& } \\
\text { Quarrying }\end{array}$ & & 0.0825 \\
\hline
\end{tabular}

Situation 3 (Table-6) shows four cases in which public investment crowds in private investment, and there is an increase in employment, but there is a drop in output. For such unusual results one plausible reason may be that the depreciation rate in these sectors is much higher and outweighs the effects of new investment and labor absorption. Some other explanations may also be provided. For example, in the case of the agriculture sector, the negative impact of water and electricity shortages perhaps outweigh the positive impact of private investment and employment. In the same manner, in mining \& quarrying, perhaps the reduction in foreign direct investment has outweighed the increase in private domestic investment and employment. Finally, in the case of electricity and gas distribution, for the last twenty years IPPs are the major producer of electricity, and a worsening relationship between the government and IPPs may have negatively impacted on the output of electricity which is more than the positive impact of crowding in private sector investment and an increase in employment. 


\section{Comparative Analysis of Marginal Productivity}

Corresponding to the forty-eight elasticities coefficients, we have also computed forty-eight marginal productivity (MP) coefficients. First off, we compare the size of the impact from aggregate and sectoral public investments. There are twenty-four such comparisons; eight each for private investment, output, and employment. Comparisons on the marginal productivity analysis show that the results obtained from aggregate and sectoral public investment are different, but this is not unexpected. It stands to reason that public investment made directly into a sector will have a more profound impact per rupee than aggregate public investment has on the same sector. However, estimated differences also may be because of the econometric technique and possible estimation outliers.

As Table 7 shows, in six out of eight cases, the MP of sectoral public investment on private investment in that sector is larger in magnitude than the MP of aggregate investment. Thus, most of the results go in line with the intuition that direct investments in a sector have a more powerful impact per rupee. The highest MPs of public sectoral investment on output is 6.89 in finance and insurance followed by 2.18 and 1.14 in the manufacturing and construction sectors. This implies one rupee of public investment in these sectors will generate rupees $6.89,2.18$ and 1.14 respectively. In contrast, the sum of the marginal productivities of aggregate public investment on sectoral output is less than unity. However, in only four cases is the estimated MPs for output of sectoral public investment both positive in direction and greater in magnitude than the estimated MPs of aggregate public investment. Finally, like the marginal productivity analysis on private investment, the employment effects show, that for six out of eight cases, the sectoral investment has larger positive effects than aggregate public investment.

Mathematically, the marginal products are derived from the estimated elasticities in the separate sectoral models for either aggregate or sectoral public investment. We note that given the estimated elasticities, the term that is being multiplied against the estimated elasticity (see equation 4) in the case of the models of sectoral public investment effects is going to be larger than the term that is being multiplied against the estimated elasticity in the case of the aggregate public investment effects. This is because, in calculating sectoral MPs, the denominator in the multiplied term is sectoral investment rather than aggregate investment (which will be smaller than the aggregate) thereby making the term larger for sectoral investments.

Table 7: Marginal Productivity Estimates

\begin{tabular}{|c|c|c|c|c|c|}
\hline \multirow[b]{3}{*}{ Sector } & \multicolumn{3}{|c|}{ Effects on Private Investment } & & \\
\hline & \multirow[b]{2}{*}{$\begin{array}{l}\% \text { of Private } \\
\text { Investment }\end{array}$} & \multicolumn{2}{|c|}{$\begin{array}{l}\text { Impact of Aggregate Public } \\
\text { Investment on Sectoral Private } \\
\text { Investment }\end{array}$} & \multicolumn{2}{|c|}{$\begin{array}{l}\text { Impact of Sectoral Public } \\
\text { Investment on Sectoral Private } \\
\text { Investment }\end{array}$} \\
\hline & & $\begin{array}{l}\text { MP of Aggregate } \\
\text { Public investment }\end{array}$ & $\begin{array}{c}\text { Shares of } \\
\text { Benefits (\%) }\end{array}$ & $\begin{array}{c}\text { MP of Sectoral } \\
\text { Public Investment } \\
\end{array}$ & $\begin{array}{c}\text { Shares of } \\
\text { Benefits (\%) } \\
\end{array}$ \\
\hline Agriculture & 12.09 & 0.0883 & 12.566 & 2.775 & 30.765 \\
\hline Mining \& Quarrying & 4.66 & 0.0127 & 1.801 & 0.2295 & 2.545 \\
\hline Manufacturing & 25.56 & 0.2631 & 37.429 & 4.764 & 52.816 \\
\hline Construction & 1.45 & 0.0162 & 2.307 & 0.3103 & 3.441 \\
\hline $\begin{array}{l}\text { Electricity and Gas } \\
\text { Distribution }\end{array}$ & 2.62 & 0.0734 & 10.434 & 0.0176 & 0.195 \\
\hline $\begin{array}{l}\text { Transport, Storage } \\
\text { and Communication }\end{array}$ & 18.65 & 0.0682 & 9.696 & 0.1884 & 2.089 \\
\hline $\begin{array}{l}\text { Finance and } \\
\text { Insurance }\end{array}$ & 4.71 & -0.0134 & ------- & 0.7352 & 8.15 \\
\hline Services & 27.22 & 0.1812 & 25.777 & -1.0108 & ------ \\
\hline $\begin{array}{l}\text { Sum Across the } \\
\text { Sectors }\end{array}$ & 96.96 & 0.6897 & & 8.0092 & \\
\hline $\begin{array}{r}\text { Effect of Public Inv } \\
\text { for Ag }\end{array}$ & $\begin{array}{l}\text { ment in Model } \\
\text { gate Economy }\end{array}$ & 0.6628 & & & \\
\hline
\end{tabular}




\begin{tabular}{|c|c|c|c|c|c|}
\hline \multicolumn{6}{|c|}{ Effects on Output } \\
\hline \multirow[b]{2}{*}{ Sector } & \multirow[b]{2}{*}{$\%$ of Output } & \multicolumn{2}{|c|}{$\begin{array}{l}\text { Impact of Aggregate Public } \\
\text { Investment on Sectoral Output }\end{array}$} & \multicolumn{2}{|c|}{$\begin{array}{l}\text { Impact of Sectoral Public } \\
\text { Investment on Sectoral Output }\end{array}$} \\
\hline & & $\begin{array}{l}\text { MP of Aggregate } \\
\text { Public Investment }\end{array}$ & $\begin{array}{c}\text { Shares of } \\
\text { Benefits (\%) }\end{array}$ & $\begin{array}{c}\text { MP of Sectoral } \\
\text { Public Investment }\end{array}$ & $\begin{array}{c}\text { Shares of } \\
\text { Benefits (\%) }\end{array}$ \\
\hline Agriculture & 21.38 & -0.0897 & --- & -6.8955 & ---- \\
\hline Mining \& Quarrying & 2.93 & 0.2813 & 28.013 & -0.0667 & ---- \\
\hline Manufacturing & 18.09 & 0.0696 & 6.934 & 2.1851 & 19.615 \\
\hline Construction & 2.35 & 0.0965 & 9.607 & 1.1441 & 10.27 \\
\hline $\begin{array}{l}\text { Electricity and Gas } \\
\text { Distribution }\end{array}$ & 2.33 & -0.0164 & ---- & -0.1239 & --- \\
\hline $\begin{array}{l}\text { Transport, Storage } \\
\text { and Communication }\end{array}$ & 12.67 & 0.0981 & 9.775 & 0.7884 & 7.078 \\
\hline $\begin{array}{l}\text { Finance and } \\
\text { Insurance }\end{array}$ & 4.49 & 0.311 & 30.977 & 6.8899 & 61.848 \\
\hline Services & 18.03 & 0.1475 & 14.695 & 0.1407 & 1.263 \\
\hline $\begin{array}{l}\text { Sum Across the } \\
\text { Sectors }\end{array}$ & 82.27 & 0.8979 & & 4.0621 & \\
\hline \multicolumn{2}{|c|}{$\begin{array}{r}\text { Effect of Public Investment in Model } \\
\text { for Aggregate Economy }\end{array}$} & \multicolumn{2}{|l|}{0.4665} & & \\
\hline \multicolumn{6}{|c|}{ Effects on Employment } \\
\hline & & \multicolumn{2}{|c|}{$\begin{array}{c}\text { Impact of Aggregate Public } \\
\text { Investment on Sectoral } \\
\text { Employment }\end{array}$} & \multicolumn{2}{|c|}{$\begin{array}{c}\text { Impact of Sectoral Public } \\
\text { Investment on Sectoral Employment }\end{array}$} \\
\hline Sector & $\begin{array}{c}\text { \% of Total } \\
\text { Employment }\end{array}$ & $\begin{array}{l}\text { Number of Jobs } \\
\text { (Per million Rs.) }\end{array}$ & $\begin{array}{c}\text { Shares of } \\
\text { Benefits (\%) }\end{array}$ & $\begin{array}{l}\text { Number of Jobs } \\
\text { (Per million Rs.) }\end{array}$ & $\begin{array}{c}\text { Shares of } \\
\text { Benefits (\%) }\end{array}$ \\
\hline Agriculture & 43.82 & 0.0266 & 2.49 & -96.5601 & ----- \\
\hline Mining \& Quarrying & 0.17 & -0.1982 & ----- & 0.2543 & 1.36 \\
\hline Manufacturing & 13.42 & 0.6742 & 63.13 & 16.2294 & 86.74 \\
\hline Construction & 6.24 & -0.012 & & 0.5131 & 2.74 \\
\hline $\begin{array}{l}\text { Electricity and Gas } \\
\text { Distribution }\end{array}$ & 0.7 & 0.2151 & 20.14 & 0.4435 & 2.37 \\
\hline $\begin{array}{l}\text { Transport, Storage } \\
\text { and Communication }\end{array}$ & 5.51 & 0.025 & 2.34 & 0.2461 & 1.32 \\
\hline $\begin{array}{l}\text { Finance and } \\
\text { Insurance }\end{array}$ & 0.91 & 0.1273 & 11.92 & 1.0217 & 5.46 \\
\hline Services & 14.23 & -1.3544 & ----- & -5.7192 & ---- \\
\hline $\begin{array}{l}\text { Sum Across the } \\
\text { Sectors }\end{array}$ & 85 & -0.4964 & & -83.5712 & \\
\hline \multicolumn{2}{|c|}{$\begin{array}{r}\text { Effect of Public Investment in Model } \\
\text { for Aggregate Economy }\end{array}$} & 1.8848 & & & \\
\hline
\end{tabular}

There are a number of outliers in the MPs in Table 7, especially for the sectoral investment models. In particular, for the sectoral public investment models, the magnitudes of the MPs for private investment are particularly large for agriculture, manufacturing, and services. These magnitudes are also quite large in output for agriculture and finance and insurance and in employment for agriculture, manufacturing, and services. For the sectoral public investment models, negative signs on sectoral employment and/or output are also surprising, since one might expect direct public investment in that sector to have positive effects. The negative signs might be viewed as outliers when the magnitudes are also large. This is the case in private investment for services, in output for agriculture, and in employment for agriculture and services.

For the aggregate public investment models, the only large negative coefficient is in employment for services, but there are other large MP effects that seem like outliers compared to the other MPs (see last two entries in the second column of Table 7). This is less the case for the estimated elasticities. These results further highlight the role of the coefficient used to create the MP in pushing the calculated MPs for sectoral public investment above MPs for aggregate public investment. 
Table 7 also compares the sum of estimated sectoral MPs with directly estimated aggregate public investment effects from VAR models for private investment, output and employment specified for the aggregate of the economy. This provides insight as to whether both are close to each other or not. From this, we can glean additional information on where the impact is potentially an outlier and creating problems. Table 7 shows the effects of aggregate public investment on sum of sectoral private investments is 0.6897 , while the estimated aggregate effect on aggregate private investment is 0.6628 ; implying both figures are close. In the case of output, the impact of aggregate public investment on the sum of sectoral outputs is 0.8979 , whereas the estimated aggregate effect is 0.4665 . In the case of employment, the estimated impact of aggregate public investment on the sum of sectoral employment is -0.4964 but the estimated aggregate effect of aggregate public investment on aggregate employment is 1.88. The larger difference for employment comes from a very high negative impact on employment in services sector, which is -1.35 .

The methodology and results of this study are different from earlier Pakistani studies. The methodology significantly differs from the previous studies related to Pakistan because, although some studies applied VAR/VECM models ${ }^{2}$, these methods have not been significantly explored in this context before. Previous results were merely based on impulse response graphs for measuring the nature of effects (either positive or negative) and did not compute marginal productivities and employment effects. The sectors included in these studies were also limited compared to the present study; therefore specific comparisons of results are not made with these earlier studies.

\section{Sensitivity Analysis}

\section{ELASTICITY COEFFICIENTS}

In order to test the robustness of the elasticity and marginal productivity coefficients, we have carried out sensitivity analyses. First we tested the elasticity coefficients derived from the impulse response functions. This sensitivity analysis is based on the different simulations in the main model by removing one or two variables to confirm the relationships established in the main model. Our analysis is based on two main classifications; the impact of aggregate public investment on sectoral variables and the impact of sectoral public investment on sectoral variables. We have performed initial sensitivity simulations only for the agriculture sector. We chose this sector for this exercise because it is the most important sector of Pakistan's economy but also showed the largest outliers in the main model exercise. In both cases we carried out six simulations with different permutations of the three variables: private investment, output, and employment.

Tables 8 shows the impact of aggregate pubic investment on the agriculture sector. Column 2 shows the 4 variable main model (matching Table 3), while the remaining columns are based on different model specifications. Three alternatives are for 3-variable models, deleting private investment, output or employment, respectively while retaining the other two sectoral variables. The additional sensitivity results are for bivariate models: each with just the aggregate public sector investment and a single variable for the sector. The results show that the coefficients from all of the different specifications are similar to the main results.

\footnotetext{
2 See Hyder (2001), Saeed et al. (2006), Hussain et al. (2009), and Naveed (2002), as discussed in the Introduction.
} 
Table 8: Sensitivity Analysis Case 1: Impact of Aggregate public Investment on Agriculture Sector

\begin{tabular}{|c|c|c|c|c|c|c|c|}
\hline \multirow{3}{*}{$\begin{array}{l}\text { Sectoral } \\
\text { Variables }\end{array}$} & \multicolumn{7}{|c|}{ Elasticities } \\
\hline & \multirow{2}{*}{$\begin{array}{l}4 \text { Variables } \\
\text { Main Model } \\
\end{array}$} & \multicolumn{3}{|c|}{3 Variables } & \multicolumn{3}{|c|}{2 Variables } \\
\hline & & Simulation 1 & Simulation 2 & Simulation 3 & Simulation 4 & Simulation 5 & Simulation 6 \\
\hline On Private & 0.0973 & 0.1011 & 0.0862 & ---- & 0.086237 & --- & --- \\
\hline On Output & -0.0071 & -0.0075 & ---- & -0.0069 & ---- & -0.0074 & ---- \\
\hline $\begin{array}{l}\text { On } \\
\text { Employment }\end{array}$ & 0.0002 & --- & 0.0038 & 0.0005 & ---- & --- & 0.0037 \\
\hline Main: & d(Agg_IPub) & $\mathrm{d}($ Agr_IPrv) & $\mathrm{d}($ Agr_gdp) & $\mathrm{d}($ Agr_emp) & & & \\
\hline Simulation 1: & d(Agg_IPub) & d(Agr_IPrv) & $\mathrm{d}($ Agr_gdp) & & & & \\
\hline Simulation 2: & d(Agg_IPub) & $\mathrm{d}($ Agr_IPrv) & d(Agr_emp) & & & & \\
\hline $\begin{array}{l}\text { Simulation 3: } \\
\text { Simulation 4: }\end{array}$ & $\begin{array}{l}\text { d(Agg_IPub) } \\
\text { d(Agg_IPub) }\end{array}$ & $\begin{array}{l}\text { d(Agr_gdp) } \\
\text { d(Agr_IPrv) }\end{array}$ & d(Agr_emp) & & & & \\
\hline $\begin{array}{l}\text { Simulation 5: } \\
\text { Simulation 6: }\end{array}$ & $\begin{array}{l}\text { d(Agg_IPub) } \\
\text { d(Agg_IPub) }\end{array}$ & $\begin{array}{l}\text { d(Agr_gdp) } \\
\text { d(Agr_emp) }\end{array}$ & & & & & \\
\hline
\end{tabular}

A similar exercise is carried out for sectoral public investment in the agriculture sector and is presented in Table 9. The results of these simulations are also consistent with the main model and show more precision than in aggregate public investment.

Table 9: Sensitivity Analysis Case 2: Impact of Sectoral Public Investment on Agriculture Sector

\begin{tabular}{|c|c|c|c|c|c|c|c|}
\hline \multirow{3}{*}{$\begin{array}{c}\text { Sectoral } \\
\text { Variables }\end{array}$} & \multicolumn{7}{|c|}{ Elasticities } \\
\hline & \multirow{2}{*}{$\begin{array}{l}4 \text { Varables } \\
\text { Main Model }\end{array}$} & \multicolumn{3}{|c|}{3 Variables } & \multicolumn{3}{|c|}{2 Variables } \\
\hline & & Simulation 1 & Simulation 2 & Simulation 3 & Simulation 4 & Simulation 5 & Simulation 6 \\
\hline $\begin{array}{l}\text { On Private } \\
\text { Investment }\end{array}$ & 0.0174 & 0.0124 & 0.0216 & --- & 0.018681 & --- & --- \\
\hline On Output & -0.0031 & -0.0026 & --- & -0.003 & ---- & -0.0002 & --- \\
\hline $\begin{array}{l}\text { On } \\
\text { Employment }\end{array}$ & -0.0039 & --- & -0.005 & -0.0038 & ---- & ---- & -0.0102 \\
\hline Main: & $\mathrm{d}($ Agr_IPub) & d(Agr_IPrv) & $\mathrm{d}($ Agr_gdp) & d(Agr_emp) & & & \\
\hline Simulation 1: & $\mathrm{d}$ (Agr_IPub) & $\mathrm{d}($ Agr_IPrv) & $\mathrm{d}($ Agr_gdp) & & & & \\
\hline Simulation 2: & d(Agr_IPub) & $\mathrm{d}($ Agr_IPrv) & d(Agr_emp) & & & & \\
\hline Simulation 3: & $\mathrm{d}($ Agr_IPub) & d(Agr_gdp) & d(Agr_emp) & & & & \\
\hline Simulation 4: & $\mathrm{d}$ (Agr_IPub) & d(Agr_IPrv) & & & & & \\
\hline Simulation 5: & $\mathrm{d}$ (Agr_IPub) & d(Agr_gdp) & & & & & \\
\hline Simulation 6: & $\mathrm{d}($ Agr_IPub) & $\mathrm{d}($ Agr_emp) & & & & & \\
\hline
\end{tabular}

\section{MARGINAL PRODUCTIVITY COEFFICIENTS}

The second set of sensitivity analyses aim to test the robustness of the marginal productivity coefficients. Long term accumulated marginal productivity values shown in Table 7 are obtained by multiplying the accumulated long term elasticities with the average ratio of policy variable to the response variable during the last ten years of the sample period (2001-2011). The reason to use an average of the last ten years is to avoid the cyclical fluctuations in public investment. The choice of an average ratio of the last ten years is very common in the existing literature (Pereira and Pinho, 2011); Pereira and Andraz, 2007; Pina and Aubyn, 2006; and Pereira and Andraz, 2005), however some other studies used a five year average and/or a whole sample average (Pereira and de Frutos, 1999; Pereira and Segales, 2001).

In Tables 10 and 11, we have compared marginal productivities of the entire period with the average of the last ten years. We have also done this analysis for 1964-75, 1976-87, and 1988-99. For the first three sub-periods, the results are close, but the marginal productivities of the last ten years are different and, in most of the observations, they are higher than the other three sub-periods. Therefore; the average of the entire period, in most of the cases, is higher than the first three sub-periods but less than the last sub- period. 
Table 10: Long Term Accumulated Marginal Productivity Variations of Aggregate Public Investment

\begin{tabular}{|c|c|c|c|c|c|c|}
\hline \multirow[b]{3}{*}{ Sector } & \multicolumn{2}{|c|}{ On Private Investment } & \multicolumn{2}{|c|}{ On Output } & \multicolumn{2}{|c|}{ On Employment } \\
\hline & \multicolumn{4}{|c|}{ Average MP } & \multicolumn{2}{|c|}{ Average Number of Jobs (per million Rs) } \\
\hline & Entire Period & Last 10 Years & Entire Period & Last 10 Years & Entire Period & Last 10 Years \\
\hline Agriculture & 0.0577 & 0.0883 & -0.0631 & -0.0897 & 0.0453 & 0.0266 \\
\hline Mining \& Quarrying & 0.0069 & 0.0127 & 0.1577 & 0.2813 & -0.3189 & -0.1982 \\
\hline Manufacturing & 0.174 & 0.2631 & 0.045 & 0.0696 & 0.9901 & 0.6742 \\
\hline Construction & 0.0133 & 0.0162 & 0.0719 & 0.0965 & -0.0166 & -0.012 \\
\hline $\begin{array}{l}\text { Electricity and Gas } \\
\text { Distribution }\end{array}$ & 0.0566 & 0.0734 & -0.0121 & -0.0164 & 0.3217 & 0.2151 \\
\hline $\begin{array}{l}\text { Transport, Storage } \\
\text { and Communication }\end{array}$ & 0.0381 & 0.0682 & 0.0621 & 0.0981 & 0.0355 & 0.025 \\
\hline $\begin{array}{l}\text { Finance and } \\
\text { Insurance }\end{array}$ & -0.0073 & -0.0134 & 0.1918 & 0.311 & 0.1415 & 0.1273 \\
\hline Services & 0.1172 & 0.1812 & 0.1005 & 0.1475 & -1.8471 & -1.3544 \\
\hline Aggregate & 0.4166 & 0.6628 & 0.31 & 0.4665 & 2.8815 & 1.8848 \\
\hline
\end{tabular}

Table 10 provides evidence that the reported marginal productivities of aggregate public investment on the basis of an average of the last ten years are not very different from the whole sample's average marginal productivities. Similarly, Table 11 presents the differences in marginal productivity for the sectoral model; where in a few cases, the differences are large. For example, in the agriculture and manufacturing sectors, the differences are large for sectoral public investments for output, private investment, and employment. Similarly, the difference is large for employment in the services sector.

Table 11: Long Term Accumulated Marginal Productivity Variations of Sectoral Public Investment

\begin{tabular}{|c|c|c|c|c|c|c|}
\hline \multirow[b]{3}{*}{ Sector } & \multicolumn{2}{|c|}{ On Private Investment } & \multicolumn{2}{|c|}{ On Output } & \multicolumn{2}{|c|}{ On Employment } \\
\hline & \multicolumn{4}{|c|}{ Average MP } & \multicolumn{2}{|c|}{ Average Number of Jobs (per million Rs } \\
\hline & Entire Period & Last 10 Years & Entire Period & Last 10 Years & Entire Period & Last 10 Years \\
\hline Agriculture & 0.3598 & 2.775 & -0.964 & -6.8955 & -32.712 & -96.5601 \\
\hline Mining \& Quarrying & 0.1867 & 0.2295 & -0.0559 & -0.0667 & 0.6112 & 0.2543 \\
\hline Manufacturing & 1.0063 & 4.764 & 0.4506 & 2.1851 & 7.6117 & 16.2294 \\
\hline Construction & 0.2695 & 0.3103 & 0.9044 & 1.1441 & 0.7527 & 0.5131 \\
\hline $\begin{array}{l}\text { Electricity and Gas } \\
\text { Distribution }\end{array}$ & 0.0117 & 0.0176 & -0.0789 & -0.1239 & 0.5736 & 0.4435 \\
\hline $\begin{array}{l}\text { Transport, Storage } \\
\text { and Communication }\end{array}$ & 0.1172 & 0.1884 & 0.5556 & 0.7884 & 0.3888 & 0.2461 \\
\hline $\begin{array}{l}\text { Finance and } \\
\text { Insurance }\end{array}$ & 0.4381 & 0.7352 & 4.6903 & 6.8899 & 1.254 & 1.0217 \\
\hline Services & -0.7734 & -1.0108 & 0.1134 & 0.1407 & -9.228 & -5.7192 \\
\hline Aggregate & 0.4166 & 0.6628 & 0.31 & 0.4665 & 2.8815 & 1.8848 \\
\hline
\end{tabular}

\section{CONCLUSIONS AND POLICY IMPLICATIONS}

Our study provides empirical evidences of the effectiveness of public investment on private investment, output and employment. In the literature, the production function approach is commonly applied for such an analysis. This study incorporates the VAR methodology; treating all variables as endogenous and also allows capturing the dynamic feedback effect of public investment on private investment, employment, and output.

This paper is one of the very few attempts in Pakistan at estimating the long-term elasticities and marginal productivities of sectoral public investment. The paper also compares the effectiveness of public investment at the sectoral level with the aggregate level. We use data from eight sectors of the Pakistan economy, mostly from 19642011 and present forty-eight elasticity coefficients (three for each sector from the sectoral public investment models and three for each sector from aggregate public investment models). For private investment, fourteen out of sixteen cases confirm a crowding-in phenomenon in Pakistan. This overwhelming majority demonstrates that public investment has positive effect on private investment. As well, eleven out of sixteen elasticity coefficients show public investment has increased labor absorption, and the remaining five show labor is substituted by capital as a result of increased public investment. Similarly, the elasticity coefficients show, in eleven out of sixteen sectors, output has increased because of the change in public investment. 
These results provide important implications for government policy regarding public investment and strategies to boost private investment in the country. Overwhelming the results highlight the important lesson that public investment attracted private investment in Pakistan in the past and, therefore, to attract private investment in future, the government of Pakistan should increase public investment. This lesson can also be learned from the experience of several developing countries, particularly India. In the last twenty years India engaged in very high public investment, which was accompanied by high fiscal deficits, but helped lead to high economic growth. Similarly, in the 1960s and 1980s in Pakistan, very high public investment, financed by high budget deficits, aided in high economic growth. The experience in the 1970s in Pakistan was unique in its own way. Very high amounts of public investment were spent specifically to build large public entities, rather than magnetizing high private investment, it benefited Pakistan's economy in different ways. Initially, due to high employment elasticities, the public investment absorbed a large number of workers in 1970s (Majid 2000; Pasha 2007), and subsequently it contributed to the high economic growth of the 1980s once the large entities completed their gestation periods and started production.

A recently concluded (2013) strategic agreement between the Government of Pakistan and the IMF to take the Pakistani economy out of its current crisis has important implications for the budget deficit and public investment. In an interview with Pakistani officials and journalists, Jeffrey Franks (2013) maintained:

"The government and the IMF agreed the most important issues were: (1) the very large fiscal deficit, which could no longer be financed; (2) the critically low level of international reserves; and (3) the need for structural reformsparticularly in the energy sector-to get the economy out of the low-growth trap it has been mired in for years. The program aggressively tackles all three-the deficit will come down from 8 percent of GDP to around 31/2 percent of GDP over 3 years, international reserves will be rebuilt to sustainable levels, and structural bottlenecks will be significantly eased". He also maintained "with the economy in serious trouble, Pakistan didn't have the luxury of postponing key stabilization measures”.

The results of this paper can also be used to evaluate these interventions, their implications, and their possible outcomes. Both the Government of Pakistan and the IMF agreed upon the strategy for increasing economic growth through the private sector, and private sector financing will come from the banking sector. Both parties agree this is only possible once the fiscal deficit is reduced, removing the government demand on the banking sector. This strategy assumes the economy was facing a crowding-out phenomenon of public investment, and once the budget deficit is reduced, the government will need less money from the banking system and more will be available for the private sector. However, in assuming the need for this drastic reduction in the budget deficit, the downward rigidities of current expenditures and upward rigidities of revenue are not considered. The SPDC Annual Review (2001 page 31) showed that whenever the government wished to reduce the fiscal deficit, they were unable to do so by reducing non-development expenditures or by increasing tax revenues. Almost always the government reduced the budget deficit by reducing development expenditures; creating shortages in infrastructure and negatively impacting private investment. Therefore, any suggested reduction in public investment in the next few years, to create the fiscal space necessary to reduce crowding out, is not supported by the past experiences of Pakistan's economy. The results of this study support the idea that the incentive for private investment must be provided by increasing public investment and by increasing its efficiency. This is not to deny the seriousness of the economic constraints Pakistan faces, as described by Franks.

Development priority issues also need to be discussed. Should government investment focus more on the physical infrastructure and energy sector, or should the government focus more on social infrastructure, including health and education? This paper does not provide an answer to this important question, but suggests some future work on the relative efficacy of public investments in social and physical infrastructure. A preliminary analysis of the effects of public investment in energy on sectoral economic growth by Ammad and Ahmed (2013) ${ }^{3}$ gives twenty-four sectoral elasticity coefficients from public investments in the energy sector and concludes seven out of the eight elasticities for effects on private capital demonstrate the crowding-in phenomenon. This impressive result shows that public investment in energy has a significant positive effect on private investment. In the same study, three out of eight elasticity coefficients show public energy investment increased labor absorptions, and the remaining five show labor is substituted by capital as a result of increased public investment. In the case of output, seven out of eight have positive effect on output. These results fall in line with the results that public investment in

\footnotetext{
${ }^{3} \mathrm{~A}$ summary of the results is presented in Appendix 4.
} 
energy enhances growth in Pakistan. Extending this work to education, health, and social infrastructure will provide more insight to the policy makers in resolving these issues.

In sum, we have calculated forty-eight elasticities coefficients, along with forty-eight marginal productivity coefficients. This paper compares these coefficients to highlight a few vital lessons. Overall, these results indicate that public investment is growth stimulating and is even more so at the sectoral level. The results also reveal the specific sectors where public investment has more positive effects than other sectors, possibly aiding policy makers in the sectoral allocation of funds under tight liquidity concerns. 


\section{REFERENCES}

Ammad S. and Ahmed, Qazi Masood (2013). "Dynamic Effects of Energy Sector Public Investment on Sectoral Economic Growth: Experience from Pakistan Economy," presented at the 29th AGM of Pakistan Society of Development Economist, http://www.pide.org.pk/psde/25/pdf/AGM29/papers/Syed\%20Ammad\%20Ali.pdf

Afonso António and Aubyn Miguel St (2008). "Macroeconomic Rates of Return of Public and Private Investment Crowding-In And Crowding-Out Effects,” E.C.B Working Paper Series, No 864, February 2008.

Akaike H. (1974). “A New Look At The Statistical Model Identification," IEEE Transactions On Automatic Control, Ac-19, 716-723.

Alesina, A., S. Ardagna, R. Perotti, And F. Schiantarelli (2002). "Fiscal Policy, Profits, and Investment," The American Economic Review, 92(3): 571-89

Aschauer, D. (1989a). "Is public expenditure productive?," Journal of Monetary Economics, Vol. 23, pp. 177-200

Aschauer, D. (1989b). "Does public capital crowd out private capital?," Journal of Monetary Economics, Vol.24, pp. 171-188.

Aschauer, D. (1989c). "Public investment and productivity growth in the group of seven," Economic Perspectives, Vol. 13, No. 5, pp. 17-25.

Baotai, Wang (2004). "Effectiveness of Government Expenditure On Private Investment: Canadian Empirical Evidence," Empirical Economics, Vol. 30, No. 2 (2005), pp. 493-504.

Barro, R. (1991). "Economic Growth in Cross-Section of Countries," Quarterly Journal of Economics, 106(2): $407-$ 443.

Bose Niloy, Haque M. Emranul and Osborn, Denise R. (2007). "Public Expenditure And Economic Growth: A Disaggregated Analysis For Developing Countries," The Manchester School, Vol. 75, No. 5 September 2007.

Chakraborty, Lekha (2006). "Fiscal Deficit, Capital Formation and Crowding Out: Evidence From India," NIPFM, Working Paper 06/43.

Devarajan S., Swaroop V, Zou H. (1996). “The Composition of Public Expenditure and Economic Growth,” Journal of Monetary Economics, 37: 313-344.

Dickey, D.A. and W.A. Fuller (1979). "Distribution of The Estimators For Autoregressive Time Series With A Unit Root," Journal of The American Statistical Association, 74, pp. 427-431.

Easterly, W. And Rebelo, S. (1993). "Fiscal Policy And Economic Growth: An Empirical Investigation,” Journal of Monetary Economics, 32: 417-458.

EngenEm, Skinner J. (1992). “Fiscal Policy and Economic Growth,” NBER Working Paper, 4223.

Engle, R.F., and C.W.J. Granger (1987). "Cointegration and Error Correction Representation: Estimation and Testing,” Econometrica, 55, pp. 251-276.

Folster, S. And M. Henrekson (2001). "Growth Effects of Government Expenditure and Taxation In Rich Countries," European Journal of Political Economy, 45: 1501 -1520.

Ganeli, Giovanni (2003). "Useful Government Spending, Direct Crowding-Out and Fiscal Policy Interdependence," Journal of International Money and Finance, 22: 87-103. 
Haque, N. U. And Montial P. J. (1993). "Fiscal Adjustment In Pakistan: Some Simulation Results," International Monetary Fund Staff Papers, 40(2), pp. 471-80.

Hussain, A., Muhammad Sulaiman D., Akram Kamran and LalIrfan (2009). "Effectiveness of Governmentexpenditure Crowding-In Or Crowding-Out: Empirical Evidence In Case of Pakistan," European Journal of Economics, Finance and Administrative Sciences, No. 16, 2009

Hyder, Kalim (2001). "Crowding-Out Hypothesis In A Vector Error Correction Framework: A Case Study Of Pakistan,” The Pakistan Development Review 40: 4 Part II (Winter 2001) pp. 633-650.

Jeffery, Franks (2013). "Pakistan: The Realities of Economic Reform," The International Monetary Fund's Global Economy Forum, http://blog-imfdirect.imf.org/2013/12/19/pakistan-the-realities-of-economic-reform/

Johansen, S. (1991). "Estimation and Hypothesis Testing of Cointegrating Vectors In Gaussian Vector Autoregressive Models," Econometrica, 59, pp. 1551-1580.

Johansen, S. (1995). "Likelihood-Based Inference InCointegrated Vector Autoregressive Models," Oxford: Oxford University Press.

Kamps, Christophe (2005). "The Dynamic Effects of Public Capital: VAR Evidence For 22 OECD Countries," International Tax And Public Finance, Springer, Vol. 12(4), pp. 533-558, August.

Ligthart, J. (2002). "Public capital and output growth in Portugal: an empirical analysis," European Review of Economics and Finance, Vol. 1, No. 2, pp. 3-30.

Lütkepohl, H. (1991). “Introduction to Multiple Time Series Analysis,” Berlin: Springer.

Majid, N. (2000). "Pakistan: Employment, output and productivity," Issues in development, Discussion Paper 33. Geneva, Switzerland: International Labour Organization.

Majumder Md. Alauddin (2007). "Does Public Borrowing Crowd-Out Private Investment? The Bangladesh Evidence", Policy Analysis Unit Research Department Bangladesh Bank Wp\#0708 www.Bangladeshbank.Org.Bd

Milesi-Ferretti, G. and N., Roubini. (1998). "On the Taxation of Human and Physical Capital in Models of Endogenous Growth,” Journal of Public Economics, Vol. 70, pp. 237-254.

Mittnik, S. and Neumann, T. (2001). "Dynamic Effects of Public Investment: Vector Autoregression Evidence From Six Industrialized Countries," Empirical Economics 26, pp. 429-446.

Naveed H. Naqvi (2002). "Crowding - In Or Crowding Out? Modeling The Relationship Between Public And Private Fixed Capital Formation," Pakistan Development Review, Autumn 2002, 41(3), pp. 255 - 76.

Otto, G. and Voss, G. (1994). "Public capital and private sector productivity," The Economic Record, Vol. 70, No. 209, pp. 121-132.

Parker, K. (1995). "The Behaviour of Private Investment," IMF Occasional Paper No. 134. Washington, D.C.: International Monetary Fund.

Pasha, H. A. (2007). "Inclusive Growth: The Asian Experience," Available: http://www.pndpunjab.gov.pk/user_files/File/Inclusive_Growth_31\%20Aug\%20FINAL\%20sent.pdf

Pereira, Alfredo M. and Pinho Maria De Fatima (2011). "Public Investment, Economics Performance And Budgetary Consolidation: VAR Evidence For The 12 Euro Countries," Journal of Economic Development, 2011, Vol. 36, Issue 1, pp. 1-20. 
Pereira, Alfredo M. and Andraz Jorge M. (2003). "On The Impact of Public Investment on The Performance of U.S Industries,” Public Finance Review, Vol 31 No1, January 2003, pp. 66-90.

Pereira, Alfredo and Sagales (1999). "Public Capital Formation And Regional Development In Spain," Review of Development Economics, 3(3), pp. 281-294.

Pereira, A. (2000). “Is All Public Capital Created Equal?” Review of Economics and Statistics, 82(3), pp. 513-518.

Pereira, Alfredo M. (2001). "Public Capital Formation and Private Investment: What Crowds In What?," Public Finance Review, 29 (1), 3-25.

Pereira, A. and Andraz, J. (2007). "Public investment in transportation infrastructures and industry performance in Portugal,” Journal of Economic Development, Vol. 32, pp. 1-20.

Pereira, A. M. And Andraz, J. M. (2005). "Public Investment in Transportation Infrastructure and Economic Performance in Portugal," Review of Development Economics, 9: 177-196.

Pereira, Alfredo M. \& de Frutos, Rafael Flores, (1999). "Public Capital Accumulation and Private Sector Performance," Journal of Urban Economics, Elsevier, vol. 46(2), pp. 300-322, September.

Pereira, Alfred M. \& Roca-Sagales, Oriol (2001). "Infrastructures and private sector performance in Spain," Journal of Policy Modeling, Elsevier, vol. 23(4), pp. 371-384, May.

Phillips, P.C.B. and P. Perron (1988). "Testing For A Unit Root in Time Series Regression,” Biometrika, 75, pp. 335-346.

Pina, A. and St. Aubyn, M. (2006). "How Should We Measure The Return on Public Investment In A VAR?," Economics Bulletin 8(5), pp. 1-4

Razzolini, Laura, and William F. Shughart Ii (1997). "On The (Relative) Unimportance of Balanced Budget," Public Choice 90: 215-233.

SPDC Annual Review (2001). "Social Development in Pakistan: Towards Poverty Reduction," http://www.spdc.org.pk/Publications/Annual\%20Reviews/AR-3.pdf

Saeed, Hyder. And A. Ali (2006). "The Impact of Public Investment on Private Investment: A Disaggregated Analysis," The Pakistan Development Review 45(4): 639-663

Schwarz G. (1978). "Estimating The Dimension Of A Model," The Analysis of Statistics, 6, pp. 461-464

Solow, Robert M. (1956). "A contribution to the theory of economic growth,” Quarterly Journal of Economics.70: 6594.

Sturm, J. and De Haan, J. (1995). "Is public expenditure really productive? New evidence for the U.S.A. and the Netherlands," Economic Modelling, Vol. 12, No. 1, pp. 60-72.

Voss, G. (2002). "Public and Private Investment In The United States and Canada," Economic Modeling, 19, pp. 641-664.

Wang, B. (2004). "Effects of government expenditure on private investment: Canadian empirical evidence," Empirical Economics, Vol. 30, pp. 493-504. 


\section{APPENDICES}

\section{Appendix I: Data Trends}

Figure A1: Agriculture Sector Data Trends

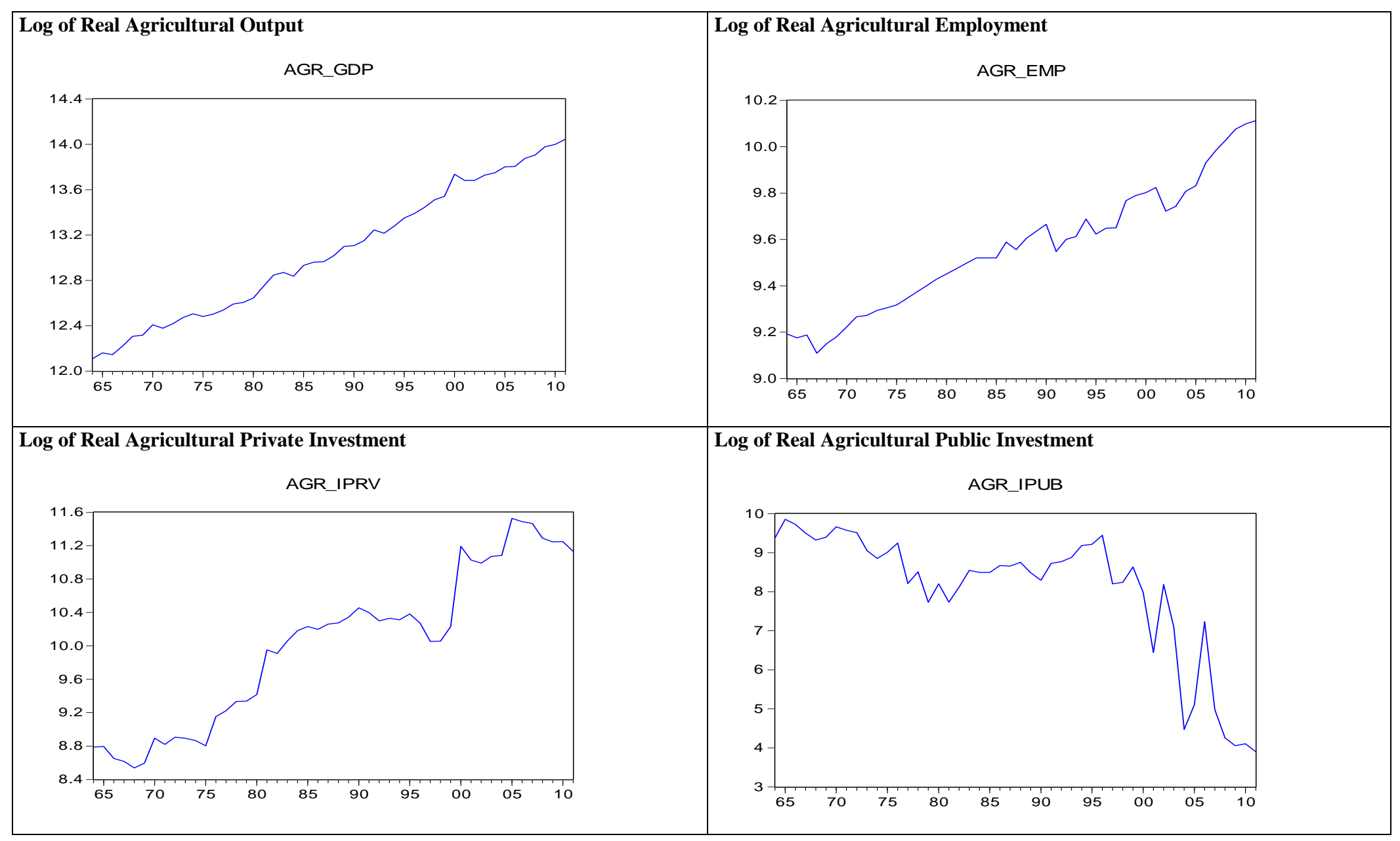


Figure A2: Mining \& Quarrying Sector Data Trends

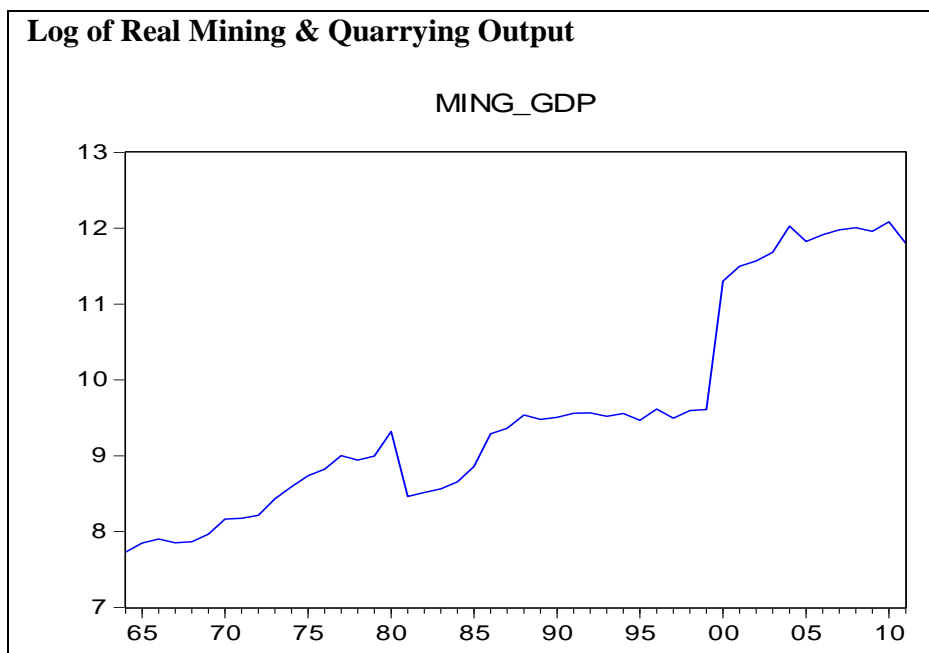

Log of Real Mining \& Quarrying Employment

MING_EMP

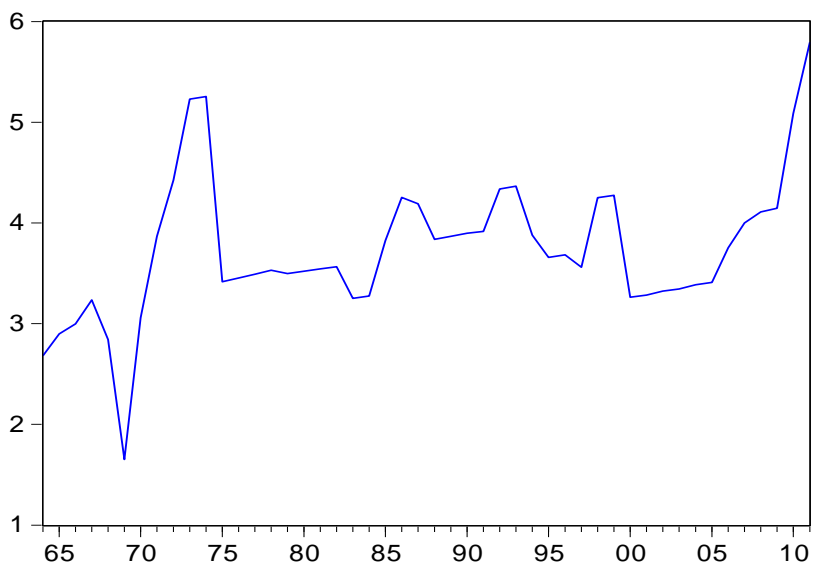

Log of Real Mining \& Quarrying Pvt Investment

Log of Real Mining \& Quarrying Public Investment

MING_IPRV

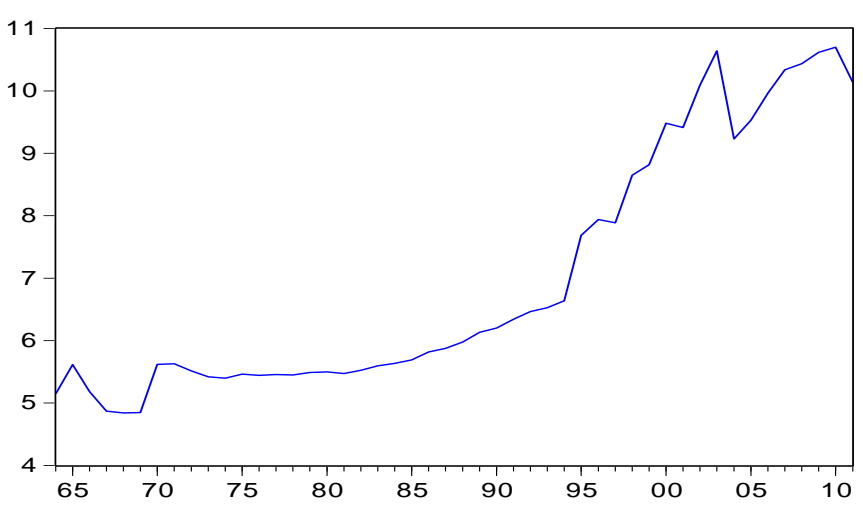

MING IPUB

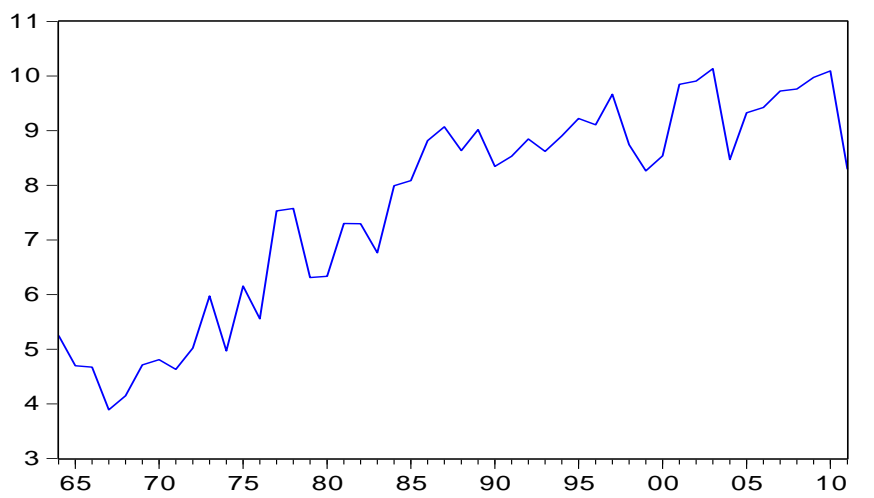


Figure A3: Manufacturing Sector Data Trends

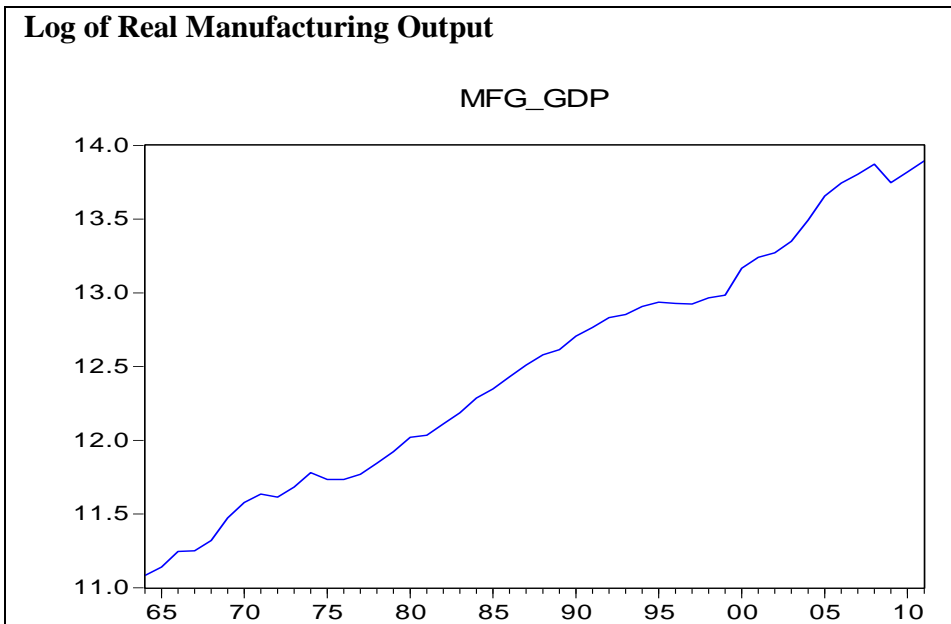

Log of Real Manufacturing Employment

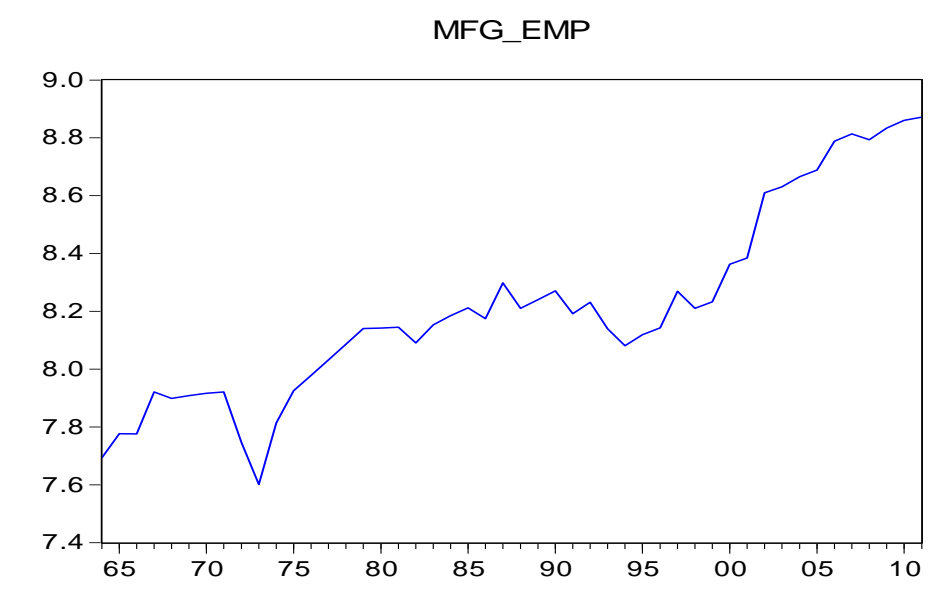

Log of Real Manufacturing Private Investment

Log of Real Manufacturing Public Investment

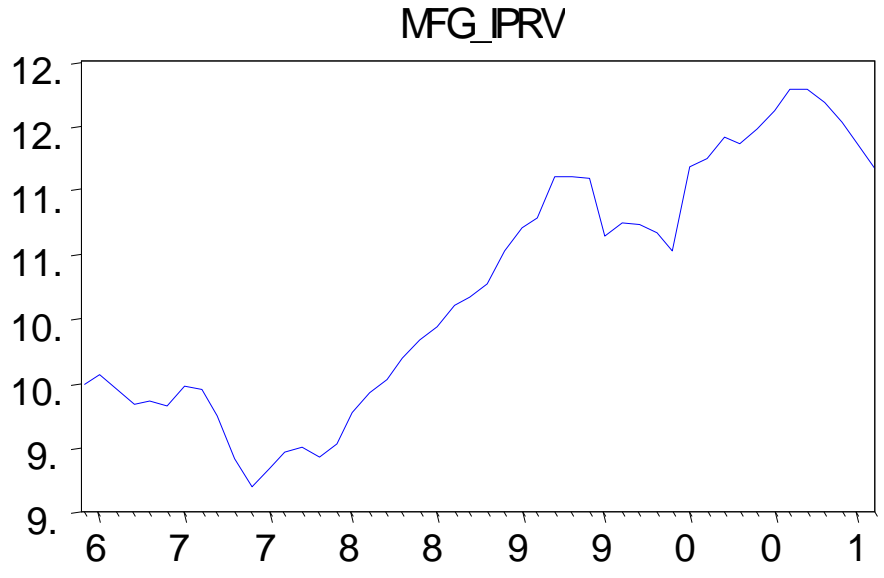

MFG_IPUB

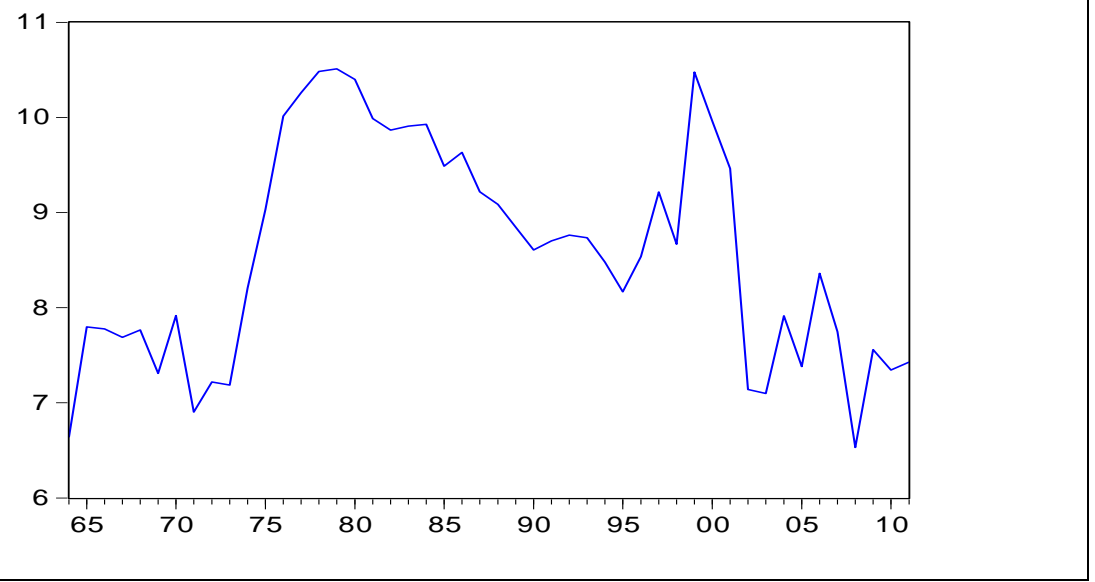




\section{Figure A4: Construction Sector Data Trends}

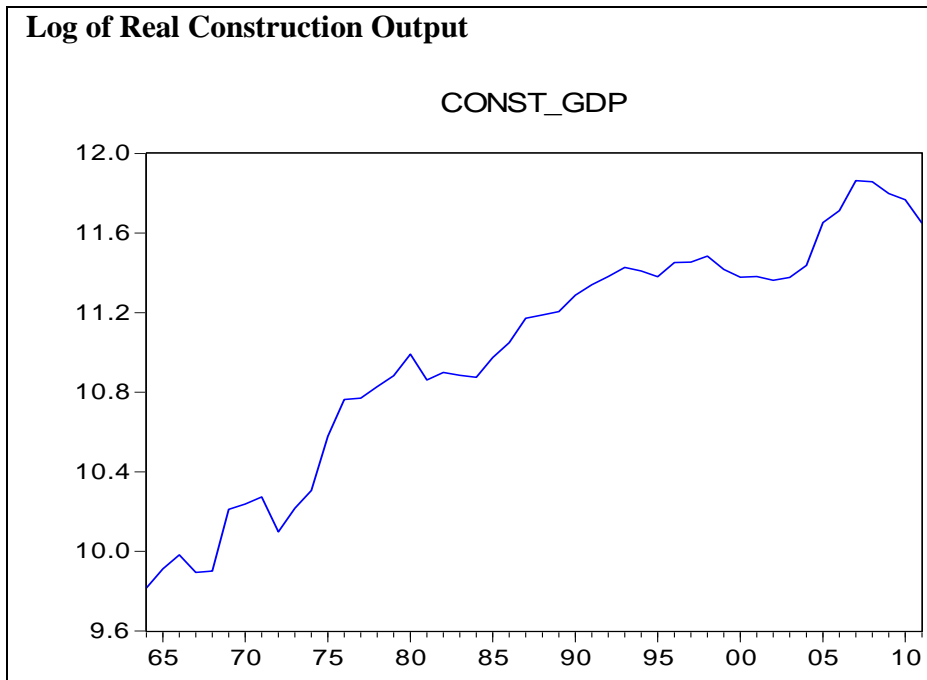

Log of Real Construction Employment

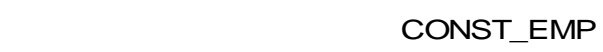

Log of Real Construction Private Investment

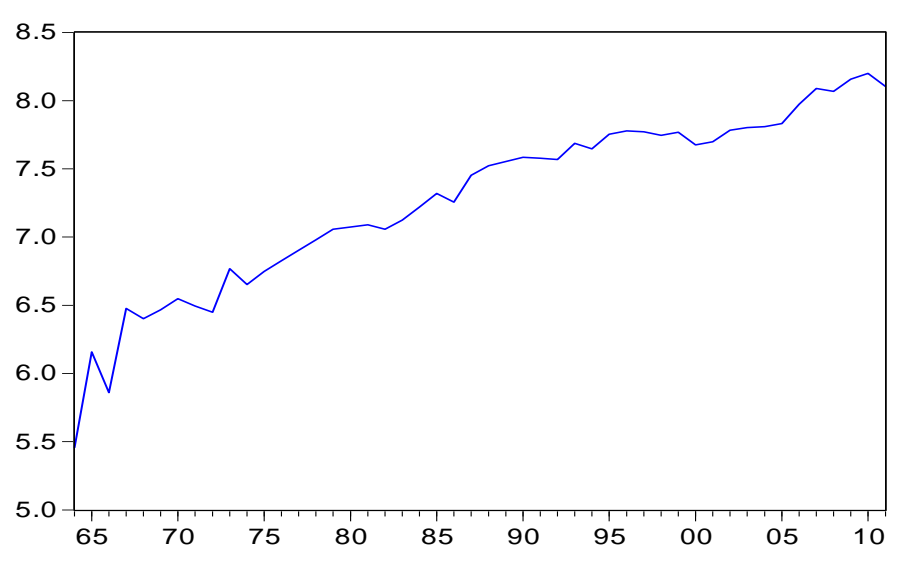

Log of Real Construction Public Investment

CONST_IPRV

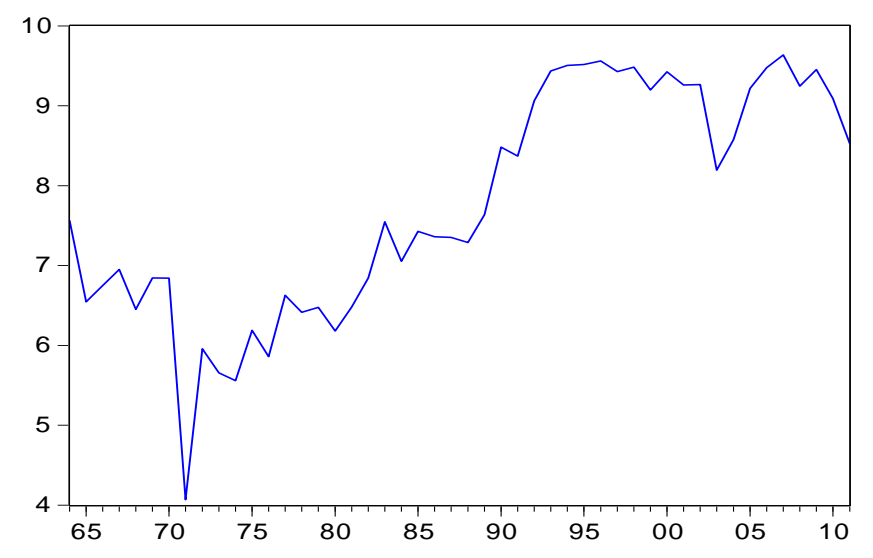

CONST_IPUB

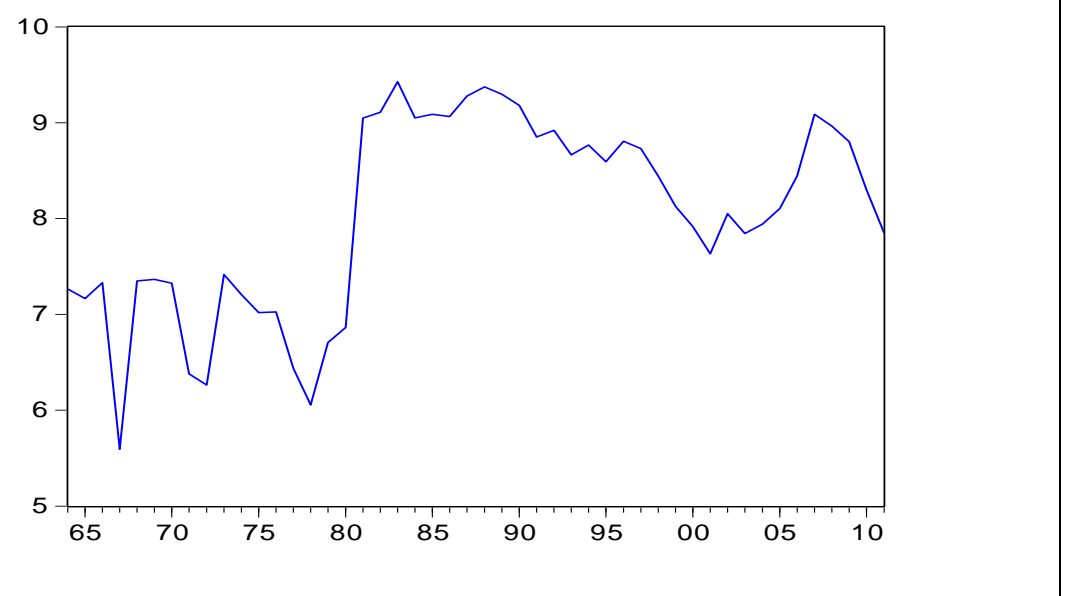




\section{Figure A5: Electricity and Gas Distribution Sector Data Trends}

Log of Real Electricity and Gas Distribution Output

ELEC_GDP

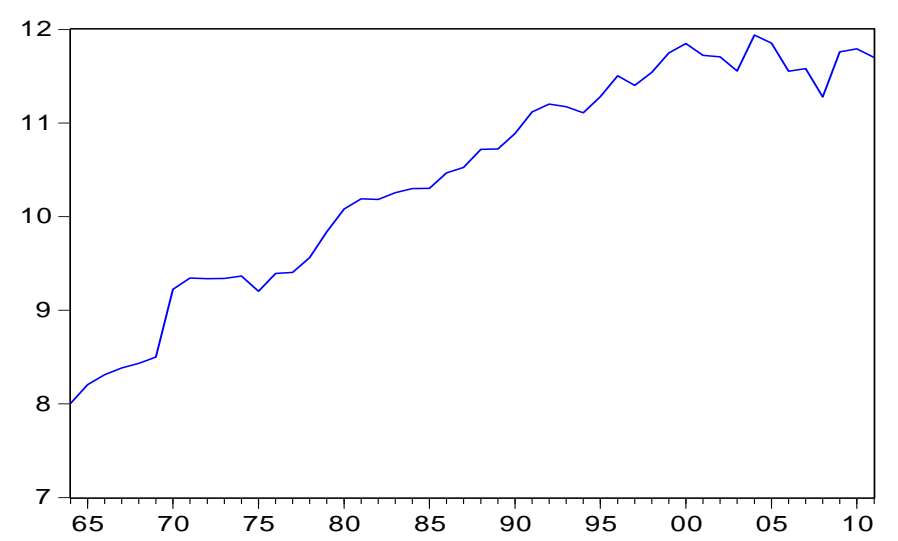

Log of Real Electricity and Gas Distribution Employment

ELEC_EMP

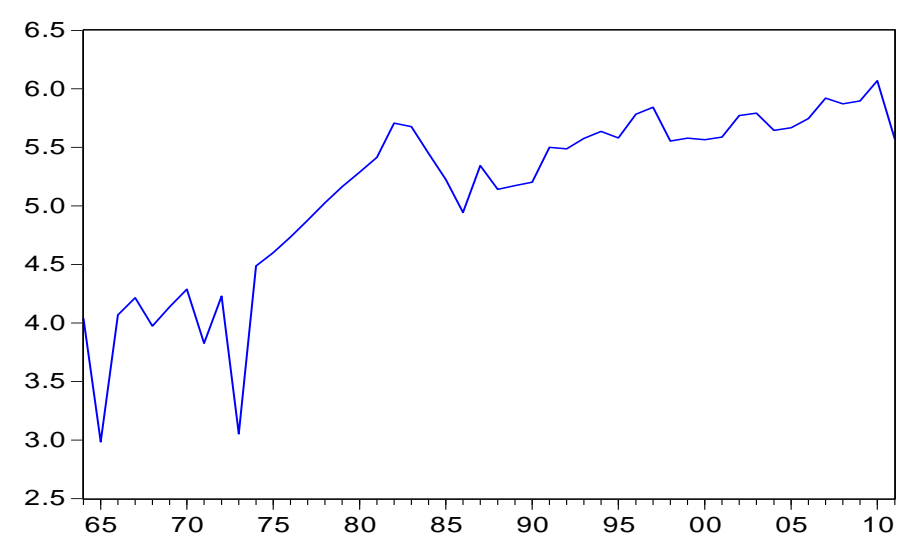

Log of Real Electricity and Gas Distribution Public Investment

ELEC IPUB

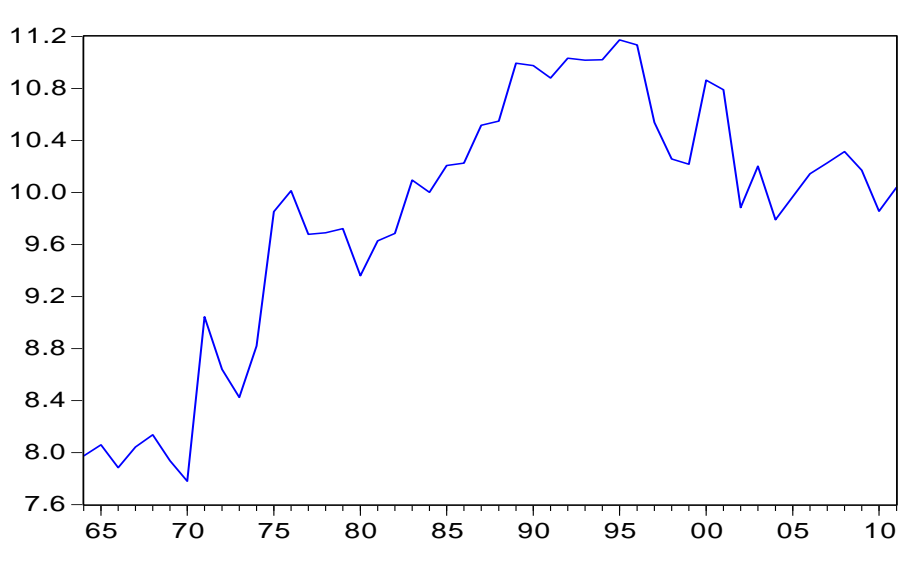


Figure A6: Transport, Storage and Communication Sector Data Trends

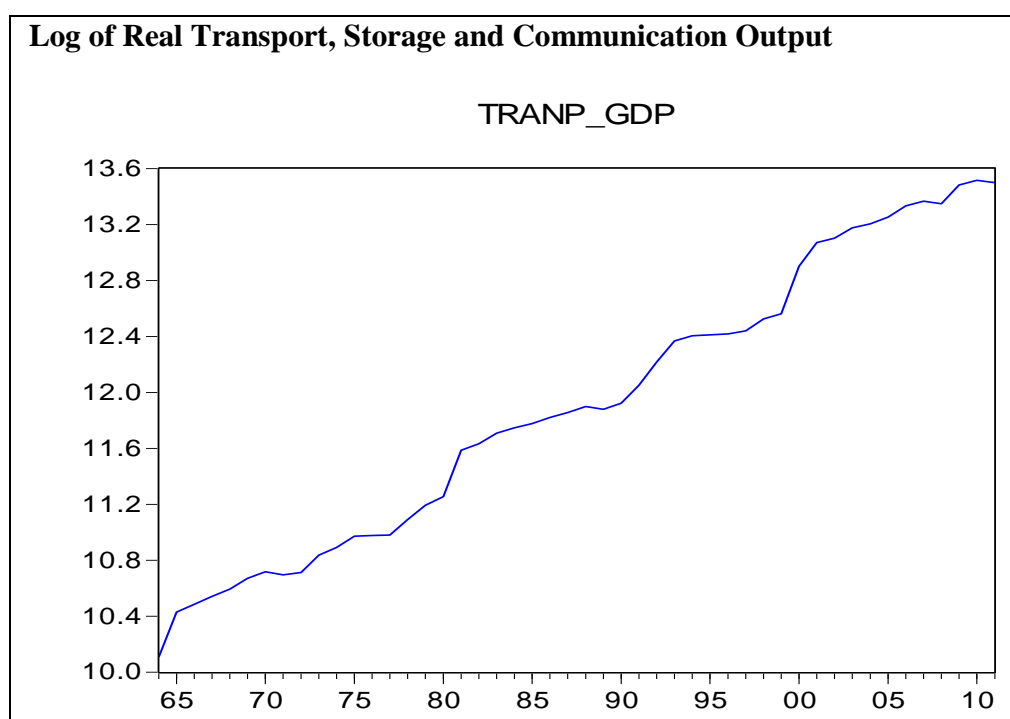

Log of Real Transport, Storage and Communication Employment

TRANP_EMP

Log of Real Transport, Storage and Communication Private Investment

TRANP_IPRV

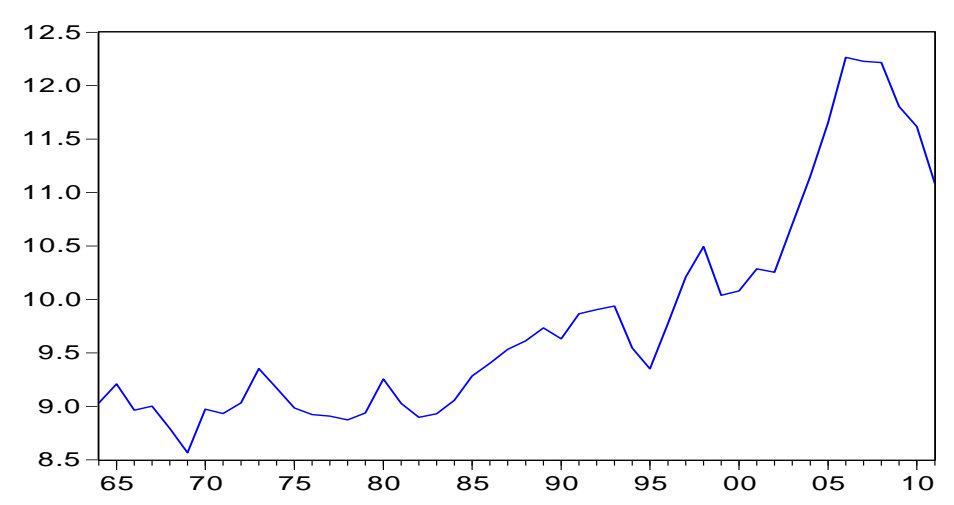

Log of Real Transport, Storage and Communication Public Investment

TRANP_IPUB

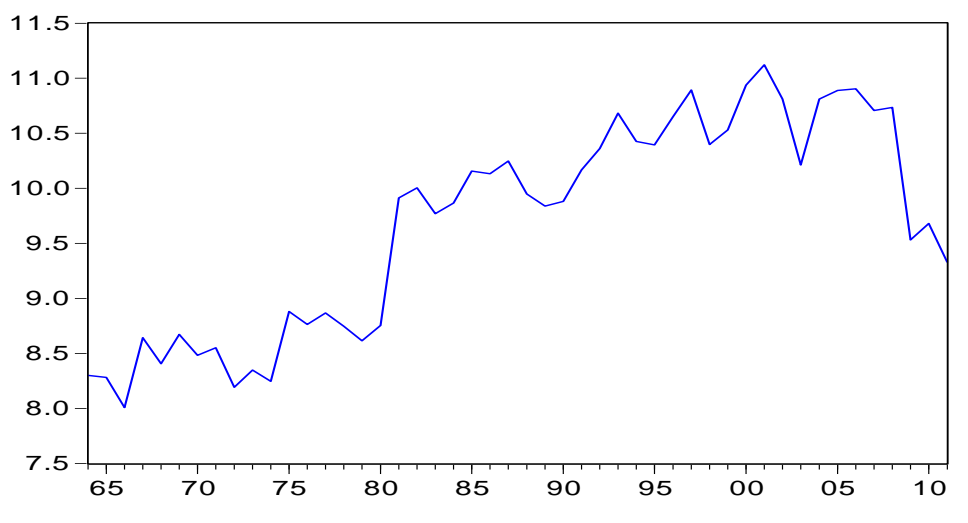




\section{Figure A7: Finance and Insurance Sector Data Trends}

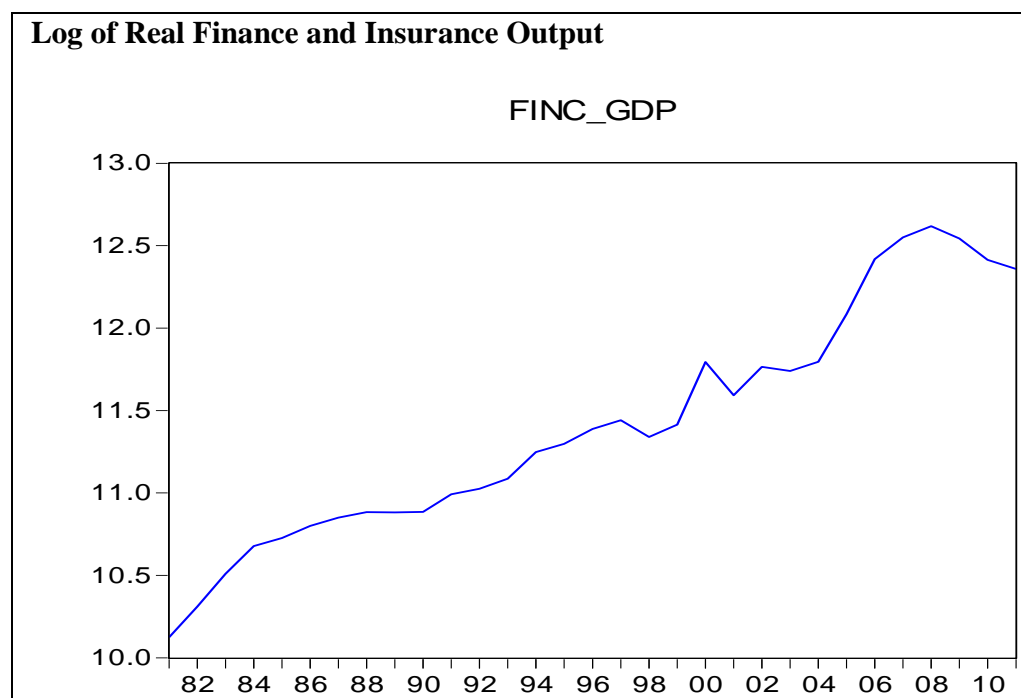

Log of Real Finance and Insurance Employment

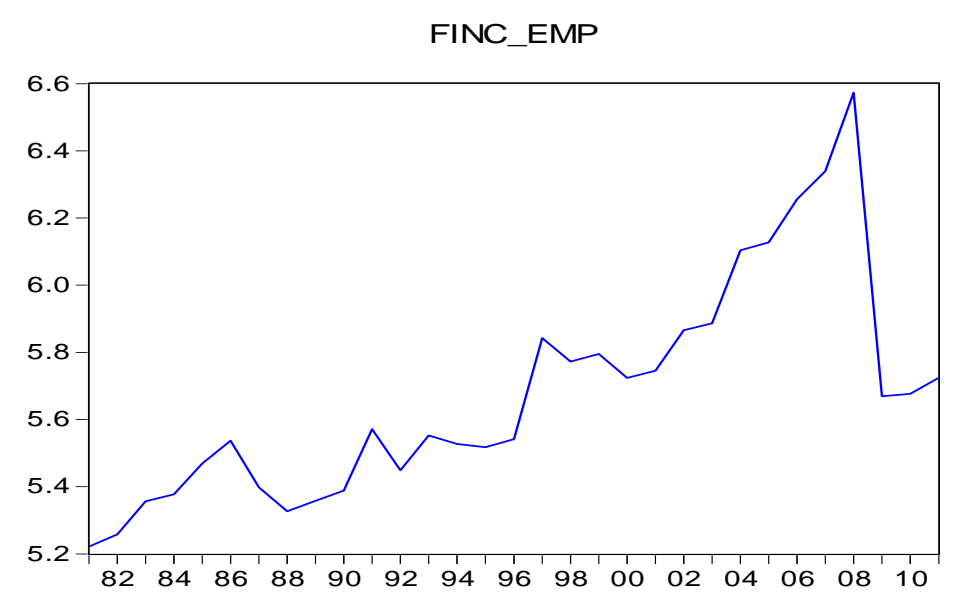

Log of Real Finance and Insurance Private Investment

Log of Real Finance and Insurance Public Investment

FINC_IPRV

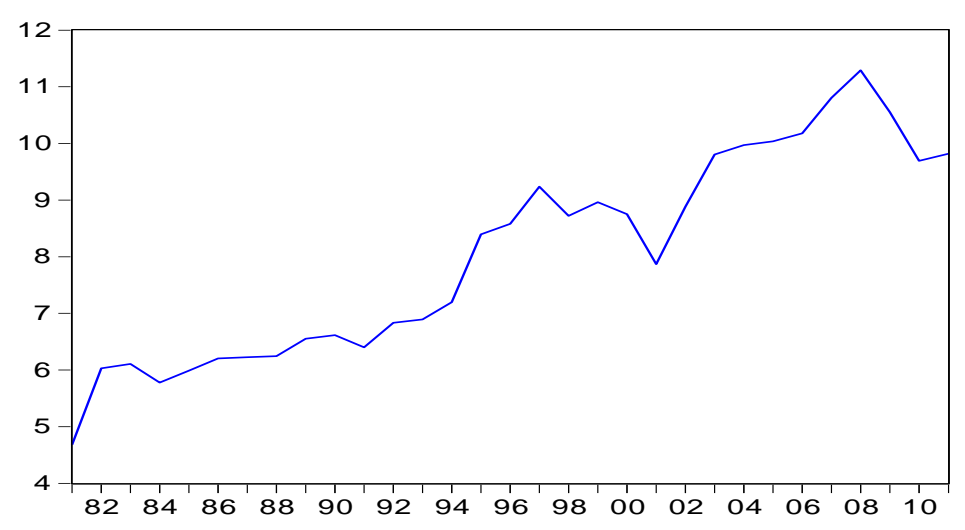

FINC_IPUB

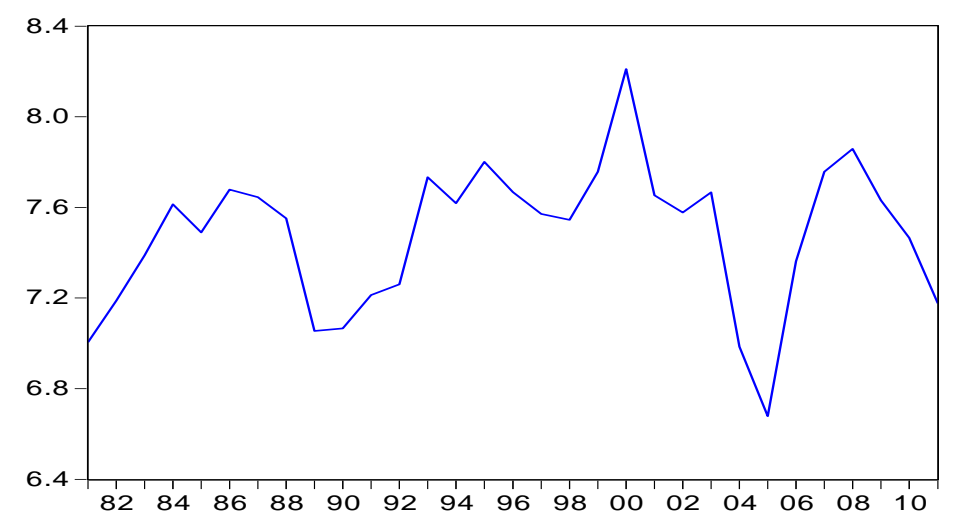




\section{Figure A8: Services Sector Data Trends}

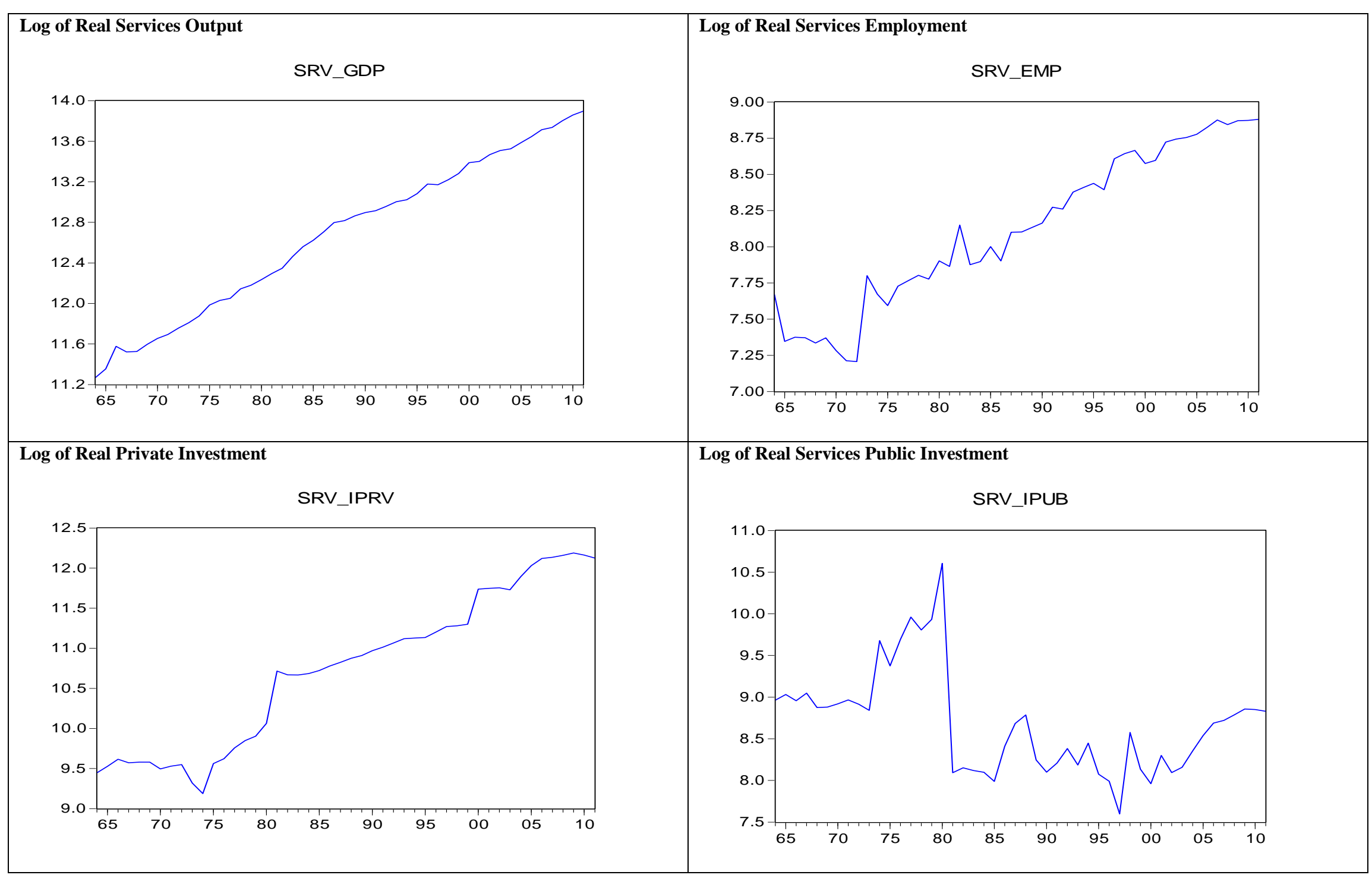




\section{Figure A9: Aggregate Economy Data Trends}

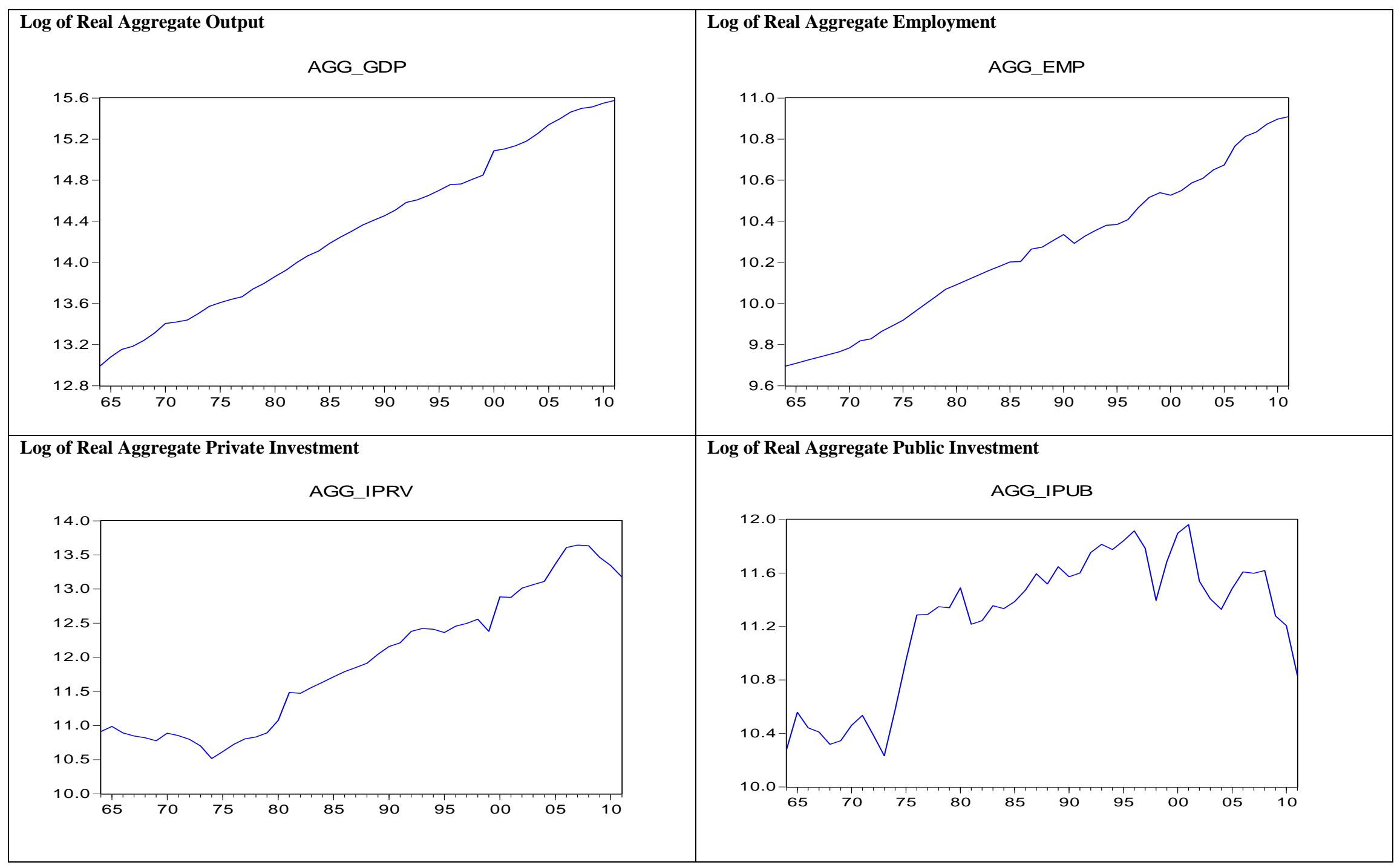




\section{Appendix 2: Robustness Tests}

\section{UNIT ROOT PHILLIPS-PERRON TEST}

Table A1: Phillips-Perron Unit Root Test Statistic Table 12 Phillips-Perron Unit Root Test Statistic

\begin{tabular}{|c|c|c|c|c|c|c|c|c|}
\hline \multicolumn{9}{|c|}{ Phillips-Perron Test Statistic } \\
\hline \multirow[b]{3}{*}{ Variables } & \multicolumn{4}{|c|}{ Level } & \multicolumn{4}{|c|}{ First Difference } \\
\hline & \multicolumn{2}{|c|}{ Without Trend } & \multicolumn{2}{|c|}{$\begin{array}{c}\text { With Trend and } \\
\text { Intercept }\end{array}$} & \multicolumn{2}{|c|}{ Without Trend } & \multicolumn{2}{|c|}{$\begin{array}{c}\text { With Trend and } \\
\text { Intercept }\end{array}$} \\
\hline & t-Statistic & Prob. $^{*}$ & t-Statistic & Prob. * & t-Statistic & Prob. ${ }^{*}$ & t-Statistic & Prob. * \\
\hline LAgr_GDP & 0.357556 & 0.9789 & -3.33903 & 0.0725 & -9.90775 & 0 & -9.90136 & 0 \\
\hline LAgr_IPub & -0.54419 & 0.8729 & -1.96172 & 0.6065 & -9.31261 & 0 & -9.99337 & 0 \\
\hline LAgr_IPrv & -0.77149 & 0.8178 & -2.67956 & 0.2494 & -6.83357 & 0 & -6.7491 & 0 \\
\hline LAgr_Emp & 1.355936 & 0.9986 & -2.66883 & 0.2537 & -8.36298 & 0 & -8.81587 & 0 \\
\hline LMing_GDP & -0.48788 & 0.8843 & -2.19104 & 0.4833 & -6.81726 & 0 & -6.7519 & 0 \\
\hline LMing_IPub & -1.40186 & 0.5735 & -2.91548 & 0.1671 & -10.021 & 0 & -17.8355 & 0 \\
\hline LMing_IPrv & 0.053368 & 0.9585 & -1.95659 & 0.6092 & -7.04307 & 0 & -7.23586 & 0 \\
\hline LMing_Emp & -2.39664 & 0.1481 & -2.75481 & 0.2207 & -5.6856 & 0 & -5.64469 & 0.0001 \\
\hline LMfg_GDP & -0.29277 & 0.9181 & -2.52216 & 0.3166 & -5.75071 & 0 & -5.68134 & 0.0001 \\
\hline LMfg_IPub & -2.35481 & 0.1599 & -2.41512 & 0.3674 & -7.55071 & 0 & -7.70645 & 0 \\
\hline LMfg_IPrv & -0.65796 & 0.8472 & -1.9867 & 0.5933 & -5.11218 & 0.0001 & -5.0532 & 0.0008 \\
\hline LMfg_Emp & -0.32159 & 0.9136 & -1.96255 & 0.6061 & -6.84341 & 0 & -6.83304 & 0 \\
\hline LConst_GDP & -2.1539 & 0.2254 & -1.57845 & 0.7865 & -5.42906 & 0 & -5.74496 & 0.0001 \\
\hline LConst_IPub & -2.06121 & 0.2608 & -2.32929 & 0.4105 & -8.12467 & 0 & -8.12181 & 0 \\
\hline LConst_IPrv & -1.26314 & 0.6389 & -3.38827 & 0.0652 & -10.3254 & 0 & -10.174 & 0 \\
\hline LConst_Emp & -3.48563 & 0.0127 & -5.75327 & 0.0001 & -15.3294 & 0 & -16.1411 & 0 \\
\hline LElec_GDP & -3.03343 & 0.039 & -1.4171 & 0.843 & -7.21362 & 0 & -9.89615 & 0 \\
\hline LElec_IPub & -1.95478 & 0.3053 & -1.36314 & 0.8589 & -7.5556 & 0 & -13.9001 & 0 \\
\hline LElec_IPrv & -1.21281 & 0.6613 & -1.61327 & 0.7726 & -5.89239 & 0 & -6.01557 & 0 \\
\hline LElec_Emp & -2.10459 & 0.2439 & -3.76239 & 0.0277 & -12.3306 & 0 & -12.9036 & 0 \\
\hline LTranp_GDP & -0.9113 & 0.776 & -3.17115 & 0.1027 & -6.59854 & 0 & -6.506 & 0 \\
\hline LTranp_IPub & -1.62116 & 0.464 & -0.94243 & 0.9421 & -7.69847 & 0 & -8.47571 & 0 \\
\hline LTranp_IPrv & -0.7372 & 0.8271 & -2.06913 & 0.549 & -4.62206 & 0.0005 & -4.56633 & 0.0034 \\
\hline LTranp_Emp & -3.04482 & 0.038 & -18.1597 & 0 & -31.5153 & 0.0001 & -33.0116 & 0 \\
\hline LFinc_GDP & -0.90725 & 0.7724 & -2.47431 & 0.3375 & -5.00199 & 0.0003 & -4.92316 & 0.0021 \\
\hline LFinc_IPub & -2.45576 & 0.1357 & -2.18371 & 0.4815 & -5.71469 & 0 & -5.98389 & 0.0001 \\
\hline LFinc_IPrv & -1.35244 & 0.5923 & -2.56214 & 0.2987 & -5.4764 & 0.0001 & -5.47194 & 0.0005 \\
\hline LFinc_Emp & -1.93783 & 0.3114 & -2.64832 & 0.2634 & -6.56416 & 0 & -6.57057 & 0 \\
\hline LSrv_GDP & -1.5097 & 0.5201 & -2.51306 & 0.3208 & -7.69589 & 0 & -7.93222 & 0 \\
\hline LSrv_IPub & -2.69943 & 0.0817 & -3.01423 & 0.1393 & -8.94482 & 0 & -8.86316 & 0 \\
\hline LSrv_IPrv & -0.31047 & 0.9154 & -2.38316 & 0.3832 & -6.38142 & 0 & -6.31137 & 0 \\
\hline LSrv_Emp & -0.07228 & 0.9464 & -6.04001 & 0 & -16.1926 & 0 & -15.7136 & 0 \\
\hline LAgg_GDP & -1.01663 & 0.7399 & -3.16816 & 0.1033 & -10.2926 & 0 & -9.94885 & 0 \\
\hline LAgg_IPub & -1.84508 & 0.3548 & 0.559083 & 0.9992 & -5.36217 & 0 & -5.77725 & 0.0001 \\
\hline LAgg_IPrv & -0.24694 & 0.9247 & -2.37602 & 0.3868 & -5.75195 & 0 & -5.70356 & 0.0001 \\
\hline LAgg_Emp & 1.100535 & 0.997 & -1.92662 & 0.6249 & -6.48744 & 0 & -6.59727 & 0 \\
\hline \multicolumn{9}{|c|}{$\begin{array}{l}\text { LAgr represents the log of agriculture sector, LMing represents the log of mining sector, LMfg represents the log of manufacturing } \\
\text { sector, LConst represents the log of construction sector, LEec represents the log of electric and gas sector, LTranp represents the log } \\
\text { of transport and communictaion sector, LFinc represents the log of finance and insurance sector, LSrv represents the log of services } \\
\text { sector, and LAgg represents the log of Aggregate economy }\end{array}$} \\
\hline & & & & & & & & \\
\hline
\end{tabular}




\section{SUMMARY OF DIAGNOSTIC RESULTS}

Table A2: Diagnostic Tests: On the Aggregate Models

\begin{tabular}{|c|c|c|c|c|}
\hline Sectors/Model & $\begin{array}{l}\text { Numbers } \\
\text { of lags }\end{array}$ & $\begin{array}{c}\text { Autocorrelation } \\
\text { Test } \\
\text { (p-value)1 } \\
\end{array}$ & $\begin{array}{c}\text { Normality Test } \\
\text { (p-value }) 2 \\
\end{array}$ & $\begin{array}{c}\text { Heteroskedasticity } \\
\text { Test } \\
\text { (p-value)3 }\end{array}$ \\
\hline Agriculture & 1 & 0.1692 & 0.0346 & 0.1611 \\
\hline Mining \& Quarrying & 1 & 0.1011 & 0 & 0.5694 \\
\hline Manufacturing & 1 & 0.0044 & 0.6889 & 0.4849 \\
\hline Construction & 1 & 0.3616 & 0 & 0.2911 \\
\hline $\begin{array}{l}\text { Electricity and Gas } \\
\text { Distribution }\end{array}$ & 1 & 0.5752 & 0 & 0.1285 \\
\hline $\begin{array}{l}\text { Transport, Storage } \\
\text { and Communication }\end{array}$ & 1 & 0.2638 & 0 & 0.4619 \\
\hline $\begin{array}{l}\text { Finance and } \\
\text { Insurance }\end{array}$ & 1 & 0.4621 & 0.0762 & 0.1216 \\
\hline Services & 1 & 0.0389 & 0 & 0.0039 \\
\hline Aggregate Pakistan & 1 & 0.0269 & 0 & 0.2324 \\
\hline \multicolumn{5}{|c|}{ 1: Based on VAR residula serial correlation LM test $w$ ith null no serial correlation } \\
\hline \multicolumn{5}{|c|}{ 2: Multivariate Jarque-Bera residual normality test. For the null hypothesis of normality } \\
\hline \multicolumn{5}{|c|}{ 3: VAR Residual Heteroskedasticity Tests. For null hypothesis of no Heteroskedasticity } \\
\hline
\end{tabular}

Table A3: Diagnostic Tests: On the Sectoral Models

\begin{tabular}{|c|c|c|c|c|}
\hline \multicolumn{5}{|c|}{ Diagnostic Test: On the Sectoral Models } \\
\hline Sectors/Model & $\begin{array}{c}\text { Numbers } \\
\text { of lags }\end{array}$ & $\begin{array}{c}\text { Autocorrelation } \\
\text { Test } \\
\text { Lag } 1 \text { ( } p \text {-value }) 1\end{array}$ & $\begin{array}{c}\text { Normality } \\
\text { Jarque-Bera Test } \\
\text { Joint (p-value)2 } \\
\end{array}$ & $\begin{array}{c}\text { Heteroskeda } \\
\text { sticity Test } \\
\text { (p-value)3 } \\
\end{array}$ \\
\hline Agriculture & 1 & 0.0411 & 0 & 0.0787 \\
\hline Mining \& Quarrying & 1 & 0.7336 & 0 & 0.9972 \\
\hline Manufacturing & 1 & 0.2966 & 0.0744 & 0.0714 \\
\hline Construction & 1 & 0.1207 & 0 & 0.0642 \\
\hline $\begin{array}{l}\text { Electricity and Gas } \\
\text { Distribution }\end{array}$ & 3 & 0.2069 & 0.728 & 0.3925 \\
\hline $\begin{array}{l}\text { Transport, Storage } \\
\text { and } \\
\text { Communication }\end{array}$ & 1 & 0.7539 & 0 & 0.5651 \\
\hline $\begin{array}{l}\text { Finance and } \\
\text { Insurance }\end{array}$ & 1 & 0.9335 & 0 & 0.2227 \\
\hline Services & 1 & 0.0108 & 0 & 0.0659 \\
\hline \multicolumn{5}{|c|}{ 1: Based on VAR residula serial correlation LM test w ith null no serial correlation } \\
\hline \multicolumn{5}{|c|}{ 2: Multivariate Jarque-Bera residual normality test. For the null hypothesis of normality } \\
\hline \multicolumn{5}{|c|}{ 3: VAR Residual Heteroskedasticity Tests. For null hypothesis of no Heteroskedasticity } \\
\hline
\end{tabular}




\section{Appendix 3: AR Roots Graphs}

Figure A10: AR Results of Aggregate Public Investment Models

Agriculture Sector Model

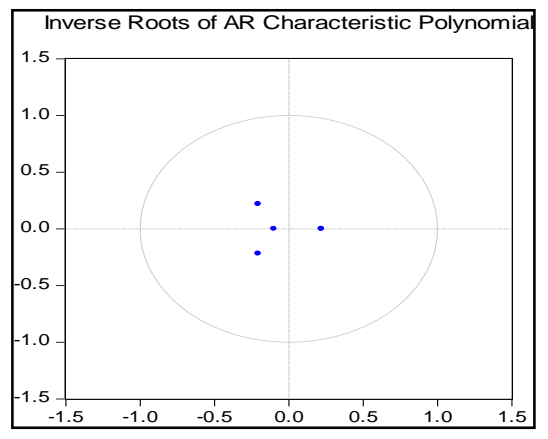

Construction Sector Model

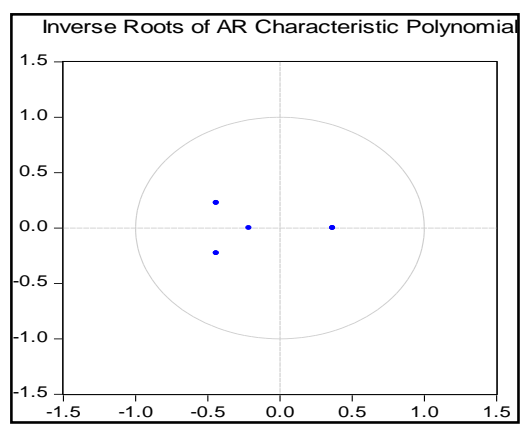

Finance Sector Model

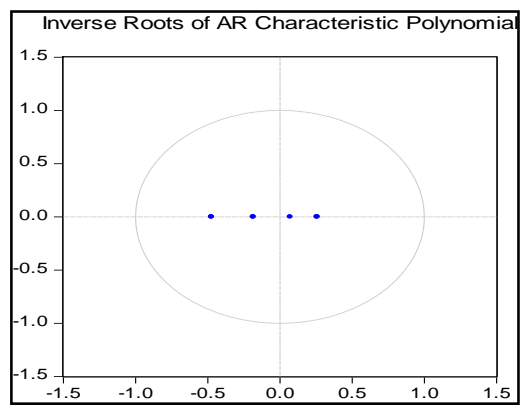

Mining Sector Model

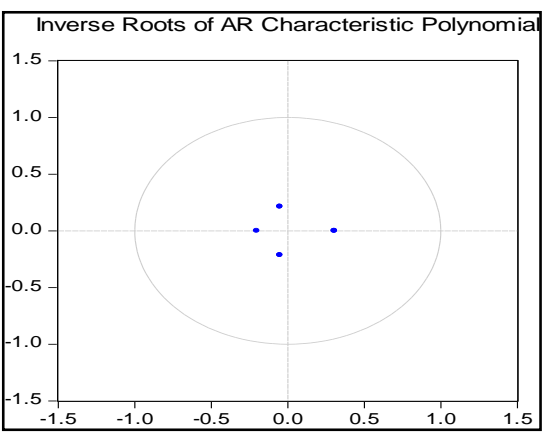

Electricity Sector Model

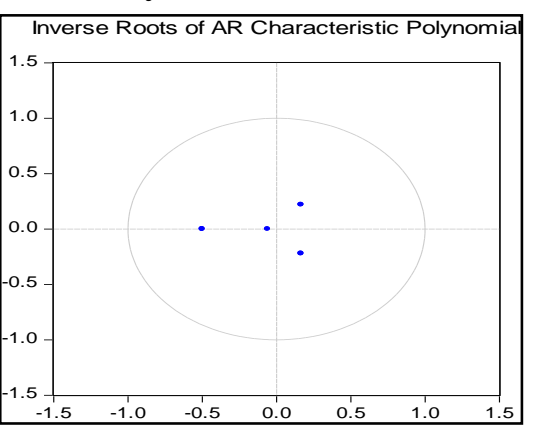

Service Sector Model

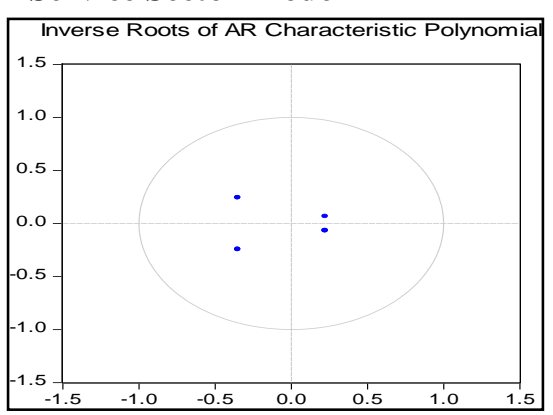

Manufacturing Sector Model

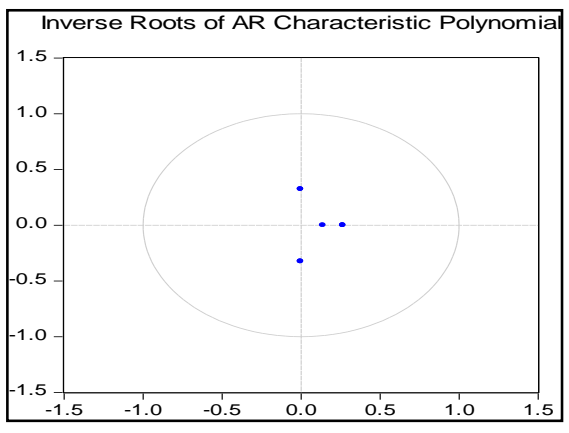

Transport Sector Model

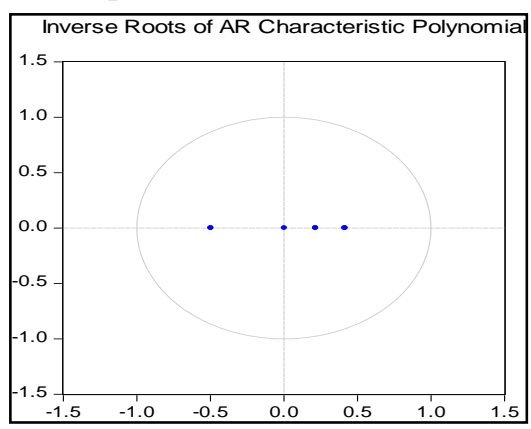

Aggregate Sector Model

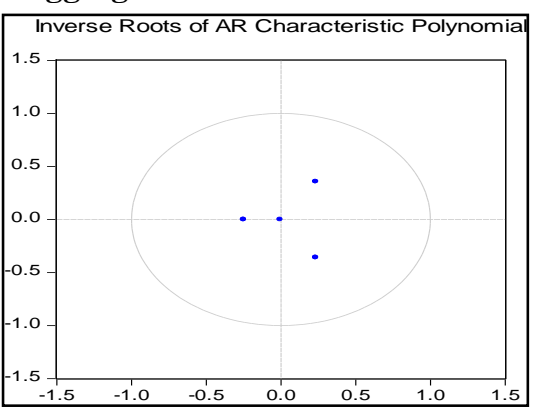




\section{Figure A11: AR Results of Sectoral Public Investment Models}

Agriculture Sector Model
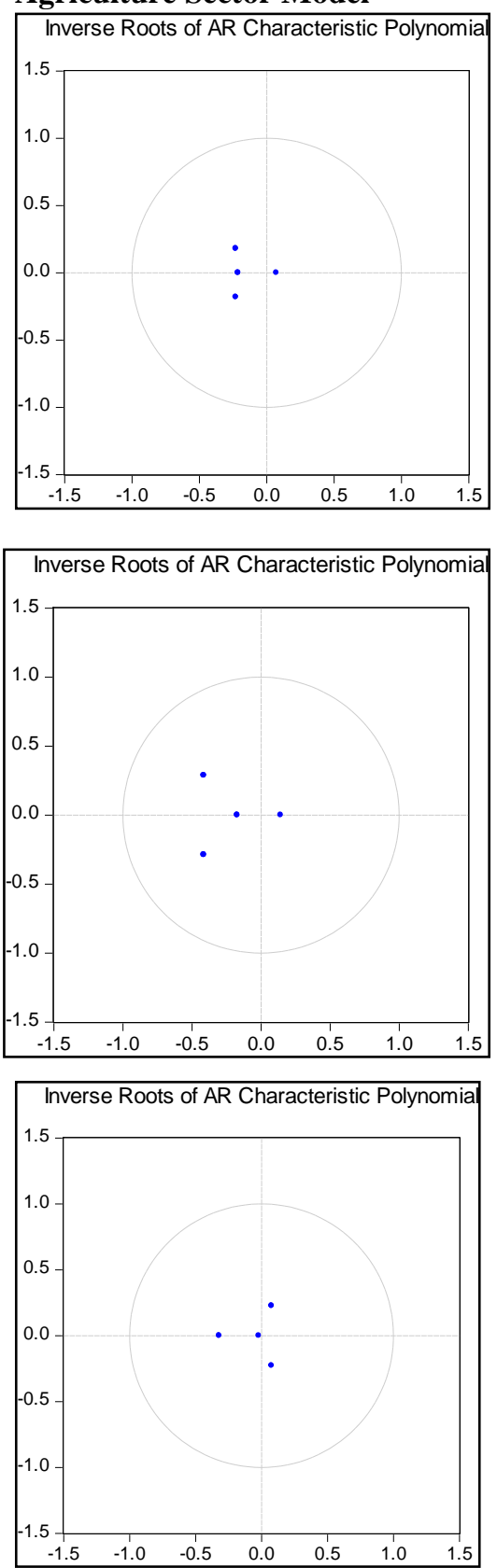

Mining Sector Model

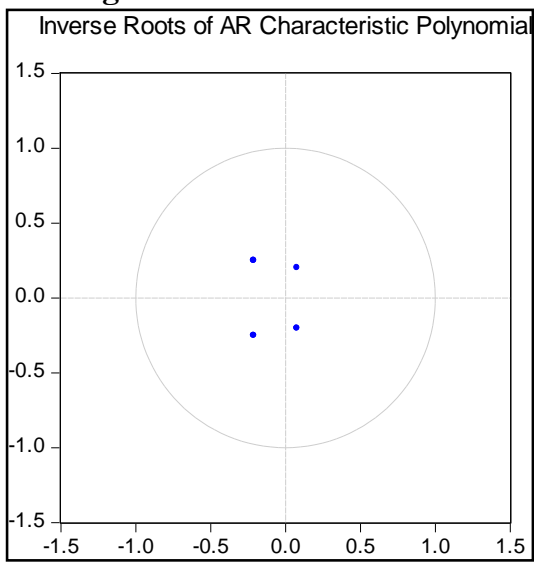

Manufacturing Sector Model

Inverse Roots of AR Characteristic Polynomia
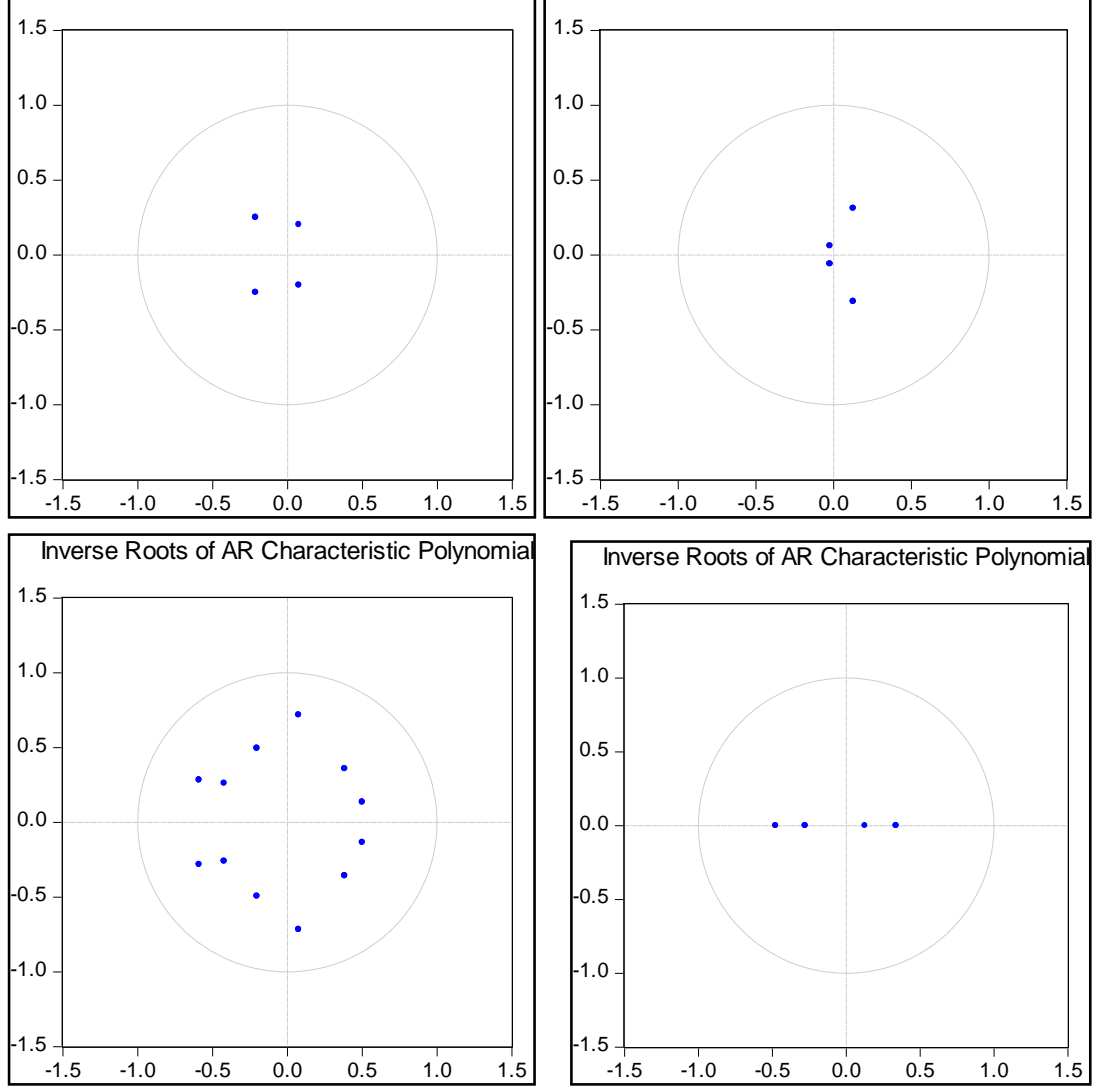

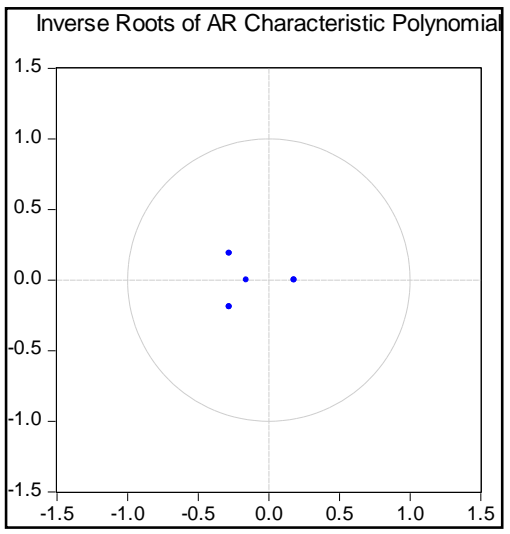




\section{Appendix 4: Energy Sector Elasticities \\ INITIAL RESULTS OF ENERGY PUBLIC INVESTMENT ON SECTORAL ECONOMIC GROWTH}

\begin{tabular}{|c|c|c|c|}
\hline \multicolumn{4}{|c|}{$\begin{array}{l}\text { Long Term Accumulated Impulse Response Effects of Public } \\
\text { Energy Investment }\end{array}$} \\
\hline Sectors & On Output & $\begin{array}{l}\text { On Private } \\
\text { Investment }\end{array}$ & $\begin{array}{l}\text { On } \\
\text { Employment }\end{array}$ \\
\hline Agriculture & + & + & + \\
\hline Mining \& Quarrying & + & + & - \\
\hline Manufacturing & + & + & - \\
\hline Construction & + & + & + \\
\hline $\begin{array}{l}\text { Electricity and Gas } \\
\text { Distribution }\end{array}$ & - & + & + \\
\hline $\begin{array}{l}\text { Transport, Storage } \\
\text { and Communication }\end{array}$ & + & + & - \\
\hline $\begin{array}{l}\text { Finance and } \\
\text { Insurance }\end{array}$ & + & - & - \\
\hline Services & + & + & - \\
\hline
\end{tabular}

\section{INTERNATIONAL FOOD POLICY RESEARCH INSTITUTE}

2033 K Street, NW | Washington, DC 20006-1002 USA | T+1.202.862.5600 | F+1.202.457.4439 | Skype: ifprihomeoffice | ifpri@cgiar.org

This Working Paper has been prepared as an output for the Pakistan Strategy Support Program, funded by USAID, and has not been peer reviewed. Any opinions stated herein are those of the author(s) and do not necessarily reflect the policies or opinions of IFPRI.

Copyright @ 2014, International Food Policy Research Institute. All rights reserved. To obtain permission to republish, contact ifpri-copyright@cgiar.org. 